WSRC-TR-2003-00279

July 2003

WSRC-TR-2003-00279 (U)

\title{
Atmospheric Prognostic and Dispersion Model Design for Use in the European ENSEMBLE Modeling Exercises (U)
}

\author{
Robert L. Buckley and Robert P. Addis
}

Savannah River Technology Center

Publication Date: July 2003

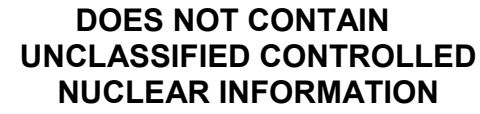

ADC \&

Reviewing

Official:

Patent Status

Date:

This internal management report is being transmitted

without DOE patent clearance, and no further

dissemination or publication shall be made of the report

without prior approval of the DOE-SR patent counsel.

Westinghouse Savannah River Company

Savannah River Site

Aiken, SC 29808

This document was prepared in connection with work done under Contract No. DE-AC09-96SR18500

with the U. S. Department of Energy 
This page intentionally left blank 
This document was prepared in conjunction with work accomplished under Contract No. DE-AC09-96SR18500 with the U. S. Department of Energy.

\section{DISCLAIMER}

This report was prepared as an account of work sponsored by an agency of the United States Government. Neither the United States Government nor any agency thereof, nor any of their employees, makes any warranty, express or implied, or assumes any legal liability or responsibility for the accuracy, completeness, or usefulness of any information, apparatus, product or process disclosed, or represents that its use would not infringe privately owned rights. Reference herein to any specific commercial product, process or service by trade name, trademark, manufacturer, or otherwise does not necessarily constitute or imply its endorsement, recommendation, or favoring by the United States Government or any agency thereof. The views and opinions of authors expressed herein do not necessarily state or reflect those of the United States Government or any agency thereof.

This report has been reproduced directly from the best available copy.

Available for sale to the public, in paper, from: U.S. Department of Commerce, National Technical Information Service, 5285 Port Royal Road, Springfield, VA 22161, phone: (800) 553-6847, fax: (703) 605-6900

email: orders@ntis.fedworld.gov

online ordering: http://www.ntis.gov/help/index.asp

Available electronically at http://www.osti.gov/bridge

Available for a processing fee to U.S. Department of Energy and its contractors, in paper, from: U.S. Department of Energy, Office of Scientific and Technical Information, P.O. Box 62, Oak Ridge, TN 37831-0062,

phone: (865)576-8401,

fax: (865)576-5728

email: $\underline{\text { reports@ adonis.osti.gov }}$ 
This page intentionally left blank 


\begin{abstract}
Many atmospheric transport and dispersion models now exist to provide consequence assessment during emergency response to near-field releases. One way of estimating the uncertainty for a given forecast is to statistically analyze an ensemble of results from several models. This paper discusses the involvement of the Savannah River Technology Center (SRTC) in a European Union program, ENSEMBLE. This program utilizes an internet-based system to ingest transport results from numerous modeling agencies. SRTC uses a prognostic atmospheric numerical model to provide three-dimensional and time-varying meteorology as input to a stochastic Lagrangian particle model. This modeling system provides better resolution than is typically available using standard large-scale weather products and Gaussian plume models.

The model design is discussed, as well as results from other modeling agencies during a series of exercises conducted over a two-year period. The exercises assumed hypothetical releases from various locations throughout Europe, with each agency delivering results as quickly as possible. The design used by SRTC is shown to successfully provide model results for each of the events in a relatively short time period, and to be versatile enough to handle assumed sources of varying geometry, strength and duration. Plots showing agreement among models for integrated concentration above a certain threshold value for the exercises indicate that the SRTC modeling system qualitatively captures similar plume characteristics provided by the other modeling agencies.
\end{abstract}


WSRC-TR-2003-00279

July 2003

TABLE OF CONTENTS

1. INTRODUCTION 1

2. ENSEMBLE BACKGROUND 1

3. MODEL BACKGROUND 3

A. Prognostic Numerical Model 3

B. Stochastic Transport Model $\quad 5$

4. RESULTS

$\begin{array}{ll}\text { A. Experiments } & 7\end{array}$

B. Threshold Agreement $\quad 8$

5. DISCUSSION/CONCLUSION 9

REFERENCES 


\section{LIST OF TABLES}

Table 1: ENSEMBLE Participating Agencies.

Table 2: RAMS Input Characteristics.

Table 3: Summary of the ENSEMBLE Scenarios with Details on the Source.

Table 4: Timing of ENSEMBLE Exercises at SRTC.

\section{LIST OF FIGURES}

Figure 1: Boundaries of the grids utilized in this study. The ENSEMBLE grid is spaced at regular latitude and longitude intervals, with results required at $0.5^{\circ}$ intervals, while the RAMS grid is polar-stereographic.

Figure 2: Boundaries of a potential multi-grid study where the inner and outer grid have the same central point. The ENSEMBLE grid is spaced at regular latitude and longitude intervals, with results required at $0.5^{\circ}$ intervals, while the RAMS grids are polarstereographic.

Figure 3: Experiment 1 Results: Release from Lerwick, Shetland Isles on 18 April, 2001.

Figure 4: Experiment 2 Results: Release from Carcassonne, France on 28 September, 2001. 20

Figure 5: Experiment 3 Results: Release from London, England on 21 November, 2001. 21

Figure 6: Experiment 4 Results: Release from Nantes, France on 5 February, 2002.

Figure 7: Experiment 5 Results: Release from Stockholm, Sweden on 16 April, 2002.

Figure 8: Experiment 6 Results: Release from Dublin, Ireland on 25 June, 2002.

Figure 9: Experiment 7 Results: Release from Glasgow, Scotland on 04 October, 2002.

Figure 10: Experiment 8 Results: Release from Mochovche, Slovakia on 03 December, 2002. 26

Figure 11: Experiment 9 Results: Release from Bratislava, Slovakia on 12 February, 2003. 27

Figure 12: Experiment 10 Results: Release of $\mathrm{Cs}^{137}$ from London, England on 11 June, 2003. 28

Figure 13: Experiment 11 Results: Release of $\mathrm{Pu}^{241}$ from London, England on 11 June, 2003. 29 


\section{INTRODUCTION}

The Savannah River Technology Center (SRTC) of the Department of Energy (DOE) Savannah River Site (SRS) has been involved with predicting the transport and dispersion of hazardous atmospheric releases for many years. Indeed, the Weather Information and Display (WIND) system (Hunter 1990) provides SRS an automated, real-time capability for consequence assessment during emergency response to local releases. The emphasis during these situations is to provide accurate guidance as quickly as possible. Consequently, atmospheric transport and dispersion models of a simple physical nature (such as Gaussian plume models) have typically been used in an effort to provide timely responses. However, use of one or two-dimensional (steady-state) winds are inadequate in conditions of high spatial and temporal variability (such as during frontal passage). Increased computing capabilities have led to the use of more sophisticated three-dimensional prognostic models that may capture some of these higher resolution phenomena. In an ideal situation, the decision-maker would want to use the "best" model each time an accident occurred. Unfortunately, due to the non-unique nature of solutions to the nonlinear equations governing the atmosphere, model " $\mathrm{A}$ " may perform better than models " $B$ " and " $C$ " in one type of weather scenario, and worse during a different situation. The use of an ensemble approach of averaging results from a variety of model solutions is beneficial to the modeler in providing the decision-maker guidance on model uncertainties.

Meteorological forecasts generated by numerical models provide individual realizations of the atmosphere. The resulting wind and turbulence fields are then used to drive atmospheric dispersion (transport and diffusion) models. Although many modeling agencies utilize ensemble-modeling techniques to determine atmospheric model sensitivities of prognostic fields (i.e. wind, temperature, radiation, etc.), the European Union has conducted two programs that are the first to examine atmospheric dispersion model output using an ensemble approach. The research discussed in this report is the result of participation in the latest of these two programs, ENSEMBLE (Galmarini et al. 2001).

There have been fifteen modeling agencies that have participated in the ENSEMBLE exercises conducted from 2001 to 2003. For each exercise, participants are asked to provide dispersion results for a given source in the form of instantaneous concentration at various levels above ground, integrated surface concentration, wet and dry deposition, and cumulative precipitation over a large domain covering Europe for forecast periods up to 72 hours. The results are sent in a format for ingestion into a web-based site that is readily available to all participants. This paper discusses the model design used by SRTC to provide input to the European ENSEMBLE program. This includes the use of a prognostic numerical model, the Regional Atmospheric Modeling System (RAMS), and a stochastic Lagrangian-based dispersion model (LPDM). Results are presented relative to other modeling agencies and a discussion of the benefits provided. 


\section{ENSEMBLE BACKGROUND}

The ENSEMBLE program is an extension of previous multi-national modeling efforts conducted in Europe following the Chernobyl accident in an effort to better understand short and long-range transport and dispersion effects in the event of a hazardous atmospheric release. These efforts are the Atmospheric Transport Model Evaluation Study (ATMES, Klug et al. 1992), the European Tracer Experiment (ETEX, Girardi et al. 1998), and the Real Time Model Evaluation (RTMOD, Bellasio et al. 1999). In ENSEMBLE, a web-based system has been implemented to allow for easy dissemination of model results. A list of the participating countries and agencies is given in Table 1. In all, there have been 23 separate models used in ENSEMBLE from 15 different agencies and 14 countries (Denmark has both the Risø National Laboratory and the Danish Meteorological Institute).

During the entire ENSEMBLE program, SRTC participated in 11 planned exercises. In addition, there was a special exercise recreating the first release during ETEX. The following variables are required at the conclusion of each exercise: 'instantaneous' concentration $\left(\mathrm{Bq} \mathrm{m} \mathrm{m}^{-3}\right)$ as averaged over the previous hour at five different levels above ground $(0,200,500,1300$, and $3000 \mathrm{~m})$, cumulative surface concentration $\left(\mathrm{Bq} \mathrm{m}^{-3}\right)$, integrated wet and dry deposition $\left(\mathrm{Bq} \mathrm{m}^{-2}\right)$, and cumulative precipitation $(\mathrm{mm})$. This output is required at $0.5^{\circ}$ intervals for a domain covering over $5000 \mathrm{~km}$ in both latitude and longitude (covering all of Europe, as well as parts of Eastern Asia and Northern Africa) at 3-hr intervals for the duration of the exercise. The specific spatial range is $15^{\circ} \mathrm{W} \leq \mathrm{LON} \leq 60^{\circ} \mathrm{E}$ and $30^{\circ} \mathrm{N} \leq \mathrm{LAT} \leq 75^{\circ} \mathrm{N}$ and the typical forecast horizon is 60 hours.

To facilitate rapid inter-comparison of model results, it is required that the results be sent to the ENSEMBLE web site (http://ensemble.ei.jrc.it) in a specific format (i.e. certain ordering of grid points along latitude and longitude, and for different levels at different forecast times). Any missing data is to be marked as ' -9 '. The title of the file to be uploaded to the site contains an agency identification number (see Table 1), the exercise number, as well as the date of the latest analyzed meteorology used in the dispersion calculations.

Typically, notification to participants of an exercise is given several weeks in advance. An alert is sent out within 30 hours of a hypothetical release. Notification occurs via email and fax. For the hypothetical releases, notification of the source characteristics commonly occurs $\sim 8$ to 10 UTC ( $\sim 0300$ to 0500 Eastern local time), even though the release does not typically occur until 12 UTC. Despite this, it is still desired to upload dispersion results for an exercise as quickly as possible to simulate the emergency situation. When the results are uploaded, a time stamp relative to the release time of the exercise is associated with the data. These results are placed in the output plots generated using the web site. The time in which users may upload results for each exercise usually remains open for several weeks. It is common for an agency to send in results at varying times into the release using updated meteorology when it becomes available. In addition, a modeling agency may submit multiple results for the same meteorology and exercise (i.e. differing combinations of meteorological and/or dispersion models, Table 1). Therefore, for any given exercise, a large number of data sets may be used in the ensemble 
averaging. For example, in exercise 9, there were 47 different model uploads, of which 22 were for different model combinations. Of these 22 models, 15 were from different agencies (i.e. Denmark had four entries from their two agencies, while Greece, Austria, the Netherlands and Germany each had two entries. All other agencies used only one combination of meteorology model and dispersion model). SRTC sends in results using the same meteorological and dispersion models, but with two different sets of meteorology. The initial results are sent in using forecast information, while a subsequent simulation is made after all analyzed meteorology for the duration of the transport calculation is received.

The web site requires a user name and password for access and contains a variety of information, including associated agencies, development notes, documentation, and publications relative to the ENSEMBLE project. For each of the exercises, information is stored for all of the uploaded model results. The user has the option of viewing each of the variables described above for a given model, or for the ensemble of a user selected grouping of models.

In addition, the user may examine the data in a variety of ways. For spatial analyses, values are assumed for a fixed time over the entire domain. This includes simple grid plots for a given model, overlap in space between two models, scatter diagrams, vertical profiles ('instantaneous' concentration at varying levels only), and agreement on threshold levels of a given variable. The latter quantity is especially useful in determining the uncertainty of plume dispersion from a large ensemble of model results. For time analyses, values are assumed for a fixed location over the entire simulation timeframe. Useful information may be found here by comparing the timeoverlap of values (in particular, 'instantaneous' concentration) between two models, or between ensembles of model results. The global analyses consider all values at any time and location, and distributions or overall tendencies to over or underestimate one data set relative to another becomes important. Typically, this implies the use of scatter diagrams and a host of statistical parameters.

\section{MODEL BACKGROUND}

\section{A. Prognostic Numerical Model}

The prognostic model used in this study is the Regional Atmospheric Modeling System (RAMS, version 3a, Pielke et al. 1992). RAMS is a three-dimensional, finite-difference numerical model used to study a wide variety of atmospheric motions ranging in size from synoptic scale phenomena such as cyclones and hurricanes, to large eddy simulations. Basic features of the model include the use of non-hydrostatic, quasi-compressible equations and a terrain-following coordinate system with variable vertical resolution. The prognostic model is used routinely at the SRS to provide forecasts on both regional and local scales. The RAMS model is capable of simulating a wide range of atmospheric motions due to the use of a nested grid system. Incorporation of topographic features occurs through the use of a terrain-following vertical coordinate system, and turbulence is parameterized using Mellor and Yamada's level 2.5 scheme (Mellor and Yamada, 1982), as modified by Helfand and Labraga (1988) for growing turbulence. 
Due to the coarse grid spacing used in this application, precipitation is generated based on the convective parameterization scheme of Kuo (1974) as modified by Tremback (1990).

Larger-scale data are available in real time from a variety of sources, including the National Oceanic and Atmospheric Administration (NOAA) and the Fleet Numerical Meteorology and Oceanography Center (FNMOC). These data are made available to the SRS via a commercial vendor and the Internet. These larger-scale data are used to generate initialization files in RAMS containing the three-dimensional larger-scale observational data (horizontal velocity components, potential temperature, pressure, and moisture) interpolated to the RAMS (polarstereographic) model grid. This interpolation is performed on isentropic and terrain-following coordinate surfaces (Pielke et al., 1992). The initialization file in RAMS corresponding to the starting time in the simulation is then used to create an initial condition for the entire threedimensional RAMS model grid. Lateral boundary conditions are also provided at various time increments (in this application, every 6 hours) using a Newtonian relaxation scheme to drive (nudge) the prognostic variables toward the forecasted large-scale values using linear interpolation in time (Davies, 1976).

The actual simulation covers a span of 84 hours, but the first 12 hours are purposely set aside while the model is 'spinning up' a realistic boundary layer. Simulations are nominally generated using analyzed dynamic meteorological fields generated by NOAA's larger-scale Global Forecast System model (GFS, a combination of the Medium Range Forecast (MRF) and Aviation model) at $\sim 190 \mathrm{~km}$ grid spacing. Forecast information for the lateral boundary conditions is available at 6-hr increments. As a backup, the Navy Operational Global Atmospheric Prediction System (NOGAPS) model from the FNMOC is utilized to generate the meteorological boundary conditions. For the NOGAPS data, information is only available out to 72 hours and at 12-hr increments.

A soil model developed by McCumber and Pielke (1981) and modified by Tremback and Kessler (1985) is used to determine surface temperatures from surface energy balances involving net radiation, turbulent latent and sensible heat flux, and soil heat flux. A loam soil is assumed for the modeling domain with initial soil moisture between 20 and 50\%. The Biosphere Atmosphere Transfer Scheme (BATS, Dickinson et al., 1986) is used for the vegetation parameterization, which further serves to modify surface fluxes. Variable fractional land properties and seasurface temperatures $\left(1^{\circ}\right.$ horizontal grid spacing) are also used for input to the model.

The RAMS input characteristics for ENSEMBLE is summarized in Table 2. The grid is chosen as a compromise between covering as much of the ENSEMBLE domain as possible and still allowing for the simulations (meteorological and dispersion) to be completed in a short timespan. Ideally, it would be better to use a nested grid system to avoid the contamination at the lateral boundaries that occurs using the nudging scheme (Warner et al., 1997). The RAMS grid is on a polar-stereographic projection, which makes it difficult to cover the regularly spaced grid required in ENSEMBLE. Figure 1 shows the differences between the two systems, revealing that the RAMS grid does not cover parts of the intended ENSEMBLE domain. 
Recently, SRTC has developed the capability to run RAMS in parallel (using an upgraded version, 4.3.0). This allows one to run at finer grid resolutions in a significantly reduced period of time by simultaneously utilizing a number of processors. Currently, the ENSEMBLE grid covering all of Europe may be run in a nested grid configuration with horizontal grid spacing of 60 and $15 \mathrm{~km}$ using nine processors in roughly two hours. While the coarse grid covers the same domain as shown in Fig. $1(\sim 5000$ to $6000 \mathrm{~km})$, the fine grid covers a domain of only $1500 \mathrm{~km}$ on a side, so it is imperative to know the source location beforehand to center the inner grid on this location. Figure 2 shows an example grid setup where the center location of each grid is the same. In this example, if the release were from London or Rome, the inner grid wind fields would not be helpful near the source. Thus, the multiple grid simulations would not be useful in an operational sense with totally unknown source locations. However, if one suspects a potential problem area, the multiple-grid simulation could be arranged in advance of the problem and be running at all times. The discussion given in this report is limited to the serial version.

\section{B. Stochastic Transport Model}

The stochastic transport model used in this study is the Lagrangian particle dispersion model (LPDM, McNider et al., 1988, Uliasz 1993). Three-dimensional winds and turbulence (Gaussian) fields from RAMS are used as input for LPDM. A large number of particles may be released and their positions tracked by numerically solving the Langevin stochastic differential equation for subgrid-scale turbulent velocites, $u_{i}^{\prime \prime}$ (Gifford 1982) and tracking the particle positions from

$$
x_{i}(t+\Delta t)=x_{i}(t)+\left(u_{i}+u_{i}^{\prime \prime}\right) \Delta t(i=1,2,3)
$$

where $x_{i}$ is the spatial direction (west-east, north-south, and vertical), $t$ is the dispersion model time, $\Delta t$ is the model timestep, and $u_{i}$ is the mean velocity component obtained from RAMS.

Each particle represents a discrete element of pollutant mass that may be used in the calculation of concentration and is assigned varying attributes, including location, turbulent velocity fluctuation, and age. It is important to note that in LPDM, a collection of virtual 'particles' makes up the mass of pollutant released into the atmosphere. A particle released in LPDM should not be confused with aerosols whose characteristics (i.e. diameter, settling velocity, etc.) may be totally different. Concentrations are estimated using the "cell" method, whereby the mass of individual particles in a physical cell is summed. The initial mass of each particle released into the atmosphere is determined from a user-defined mass release rate. This is a discrete method in which the concentration estimate is assumed to be constant throughout the sampling volume. The initial mass of each released particle is assumed to be the same for a given source location and species. The mass of each of the particles may be reduced through radioactive decay by specification of the half-life of the material. Recently, deposition removal mechanisms were added to LPDM (Buckley 2000) and are parameterized in two ways. The first method assumes constant properties in time and space in calculating deposition, while the more 
complex method determines the deposition as a function of meteorology, land-cover, and precipitation.

The mass of each released particle is reduced by dry deposition if it is transported near the surface (lowest model level), and by wet deposition if it encounters a column of air in which precipitation has occurred in the latest meteorological data set used to transport the particles. For wet deposition, mass is depleted according to the scavenging coefficient only in those regions where RAMS predicts convective precipitation at the surface. The concentration $(C$, related to mass through the cell volume) is assumed to decay following a first-order process

$$
\frac{d C}{d t}=-\Lambda C
$$

where $\Lambda$ is the scavenging coefficient (units of inverse time). For the simple case, $\Lambda$ is constant, while for the complex case, $\Lambda$ varies with the intensity of the precipitation. The total mass accumulated at the surface in a given cell due to wet deposition is determined by summing the mass loss over all grid cells in a vertical column above that cell. The instantaneous wet deposition to the surface [mass per area] is then found by dividing this mass loss by the surface area of the grid cell.

Calculation of dry deposition also requires knowledge of each particle's location and mass. If a particle enters a surface cell (the lowest model level above ground), it is subjected to mass loss. The dry deposition flux $\left(F_{d}\right)$ within a cell is determined knowing the volume $(V)$ of the grid cell, the total mass of particles in that cell $(M)$, and the deposition velocity $\left(v_{d}\right)$ of each particle:

$$
F_{d}=\frac{M}{V} v_{d}
$$

For the simple case, $v_{d}$ is assumed constant, while for the complex case, it is a function of surface conditions and meteorology. The dry deposition within a grid cell is then the product of this flux and the model time-step. This quantity can be used to determine the mass loss of each particle in a cell, assuming the mass loss is distributed equally among all particles. The updated individual particle masses are determined from the difference in the original particle mass and the incurred loss due to dry deposition.

Cumulative deposition values are continuously summed after each time-step and the mass of each LPDM particle is then updated after this entire process by subtracting out the previously determined mass losses (this mass loss also includes radioactive decay). In this manner, the mass of each particle is depleted according to various physical mechanisms, and deposition values are formulated according to this change in particle mass. The total mass remaining within each cell is then used to determine the concentrations. 
For these applications, the concentration grid cell spacing is $37.5 \mathrm{~km}$ (half the RAMS grid spacing), while the vertical spacing is the same as in RAMS. The results are interpolated to the $0.5^{\circ} \times 0.5^{\circ}$ ENSEMBLE grid where available. Points not covered by the RAMS grid are assigned missing values (see Fig. 1). In all of the regular ENSEMBLE exercises (except \#11), $\mathrm{Cs}^{137}$ is released. For $\mathrm{Cs}^{137}$, the material is assumed to be particulate in nature with a particle diameter distribution $0.2 \leq d_{p}(\mu \mathrm{m}) \leq 10.0$, a half-life of 30.17 years, and a density of 1880 $\left[\mathrm{kg} \mathrm{m}^{-3}\right]$. For Exercise 11, $\mathrm{Pu}^{241}$ was assumed, with the same particle diameter distribution, but with a half-life of 13.2 years, and a density of $19800\left[\mathrm{~kg} \mathrm{~m}^{-3}\right]$.

\section{RESULTS}

\section{A. Experiments}

There were eleven experiments conducted during the ENSEMBLE program (not including the special re-creation of ETEX experiment 1). These are described in Table 3. The first three exercises required simple sources from a single location of a uniform strength over a specified period of time. However, starting with Exercise 4, the source specifications became more complex. Line source emissions of uniform or varying strength were used in Exercises 4 and 7 , while time-varying sources were used in Exercises 5, 8, and 9. Exercises 10 and 11 actually used the same meteorology, but two distinct instantaneous releases were assumed from the same location and at the same time: $\mathrm{Cs}^{137}$ and ${ }^{\mathrm{Pu} 241}$. This was done in an effort to simulate a 'dirty bomb'. It should be noted that LPDM in its current configuration could simulate the above scenario in one exercise, but two separate runs were performed in accordance with the ENSEMBLE needs.

The timing for providing initial SRTC results to the ENSEMBLE web page is shown in Table 4 for each of the exercises. The times in the second column are relative to the time of the hypothetical release and shows that for Exercises 1, 4, and 7, the results were provided over 4 hours after the initial release. The longer time associated with Exercise 1 is attributed to testing of the procedures to generate results and upload them to the ENSEMBLE web page. For Exercise 4, the assumption of a line source created difficulties in both source characterization and computational requirements. An older version of LPDM performed the interpolation to the ENSEMBLE grid during the calculation, which was extremely expensive, especially in the event of a multiple source release. The line source in Exercise 4 was treated as follows: one source from 0 to $1000 \mathrm{~m}$ of the given rate, and another source from 1000 to $1300 \mathrm{~m}$ at the reduced rate. Subsequent to this exercise, a modified version of LPDM was created in which this interpolation was not performed. Rather, interpolation was performed during the post-processing stage using a more efficient computational procedure. For Exercise 7, the resulting time seems high due to the earlier hypothetical release time of 0700 UTC. The time for notification was usually sent out between 04:00 and 06:00 LST (Eastern standard time is five hours behind UTC). Since the releases are of a hypothetical nature, the author did not feel the need to report to work at these early local times to provide initial results. Thus, the time in which the modeler actually received 
the source term characteristics was after 05:30 LST. The local upload time reveals that provision of results has improved during the latter exercises. This is due to a better familiarity with the procedures for providing results, as well as faster computer processing speeds with which to generate the results.

\section{B. Threshold Agreement}

As indicated in a previous section, the ENSEMBLE web page provides the user with a variety of ways to examine the results of the simulations, either on an individual model basis, or as an ensemble with user-selected models. For the sake of brevity, results depicting only the agreement of integrated surface concentration at the horizon time for each of the eleven experiments (Table 3 ) are shown in Figs. 3 to 13. Agreement for integrated concentration for a lower boundary of 1.0 $\left(\mathrm{Bq} \mathrm{m}^{-3}\right)$ is shown for a number of models (UK1, DK1, SE1, etc.) in comparison with the SRTC simulation (US1, crosshatched) for Exercises 1 to 11. Since the source term was much smaller for Exercises 10 and 11, the threshold value for these experiments was set to $0.001\left(\mathrm{~Bq} \mathrm{~m}^{-3}\right)$. The chosen model simulations all use analysis meteorology that is at or before the hypothetical release time (i.e. what would be available to the modeler in a real emergency situation). The darker the shading, the more agreement among the models exists, while the lighter shading along the periphery of the footprint is likely simulated by only one or two of the models.

For exercise 1 (Fig. 3), the release from the Shetland Islands (northeast of Scotland) spreads in a southerly direction toward France and Germany, before turning to the east. One model has the plume spreading as far north and east as Finland. The US result tends to agree with the majority of the other models, except during the latter stages of the simulation, where plume migration is comparatively farther east than the other models. The release from southern France in exercise 2 (Fig. 4) indicates (from a majority of the models) a plume that moves northward through France before turning east into Germany. One of the models has the plume spreading farther east into Ukraine and western Turkey. The US simulation in this case has a bifurcated footprint with some of the pollutant spreading east into southern Scandinavia, and another lobe spreading northward toward Iceland. This latter feature is only simulated by one other model.

Figure 5 shows the results for exercise 3 for the London release. The ensemble of models predicts an eastward-directed plume through northern Germany and northern Poland. Some of the models have the plume dispersing southward into Romania and the Black Sea, and northward into southern Scandinavia. The US model agrees with most of the models for the bulk of the plume, with some northward movement into Scandinavia by the end of the simulation. Exercise 4 (Fig. 6) shows a plume headed from Nantes, France to the northeast over northern France, Germany, Poland, and the Baltic Sea. (Note that the horizon time was actually 21 UTC, 07 February. However, several of the models did not report results out to this time, so the 18 UTC results are displayed here. The unusual source starting and stopping time (see Table 3) is probably the reason for so few models providing results out to the final horizon time). The spatial spread for all models in this case is much smaller than in the previous experiments (i.e. 
higher agreement between models). The US simulation follows the general trend of the other models, with the exception of a southern lobe reaching into parts of Italy, Bosnia, and Croatia.

The release from Sweden, shown in Fig. 7 (exercise 5), indicates generally westward plume migration for a majority of the models. Simulated results from SRTC indicate a surface plume traversing south-southwest over the southern lobe of Sweden before swinging out to the west, then back toward the north over parts of the North Sea, the Norwegian Sea, Denmark and the southern portion of Norway. The SRTC results show more dispersion at this threshold than the other models. Results for exercise 6 (Fig. 8) indicate a surface plume traversing easterly through central England and into parts of Western Europe (the Baltic Sea, northern Germany and Poland, southern Sweden) and the western-most portion of Russia (see Fig. 1). Agreement between the modeling agencies is quite good for this exercise.

For exercise 7 (Fig. 9), higher percentages of agreement are confined to the North Sea. The SRTC results indicate a plume that is first directed eastward before turning southward into northern Germany. Several models predict advection of the plume into central and eastern parts of Europe (as far as $30^{\circ} \mathrm{E}$ ). The release from Mochovce, Slovak Republic (Fig. 10, exercise 8) indicates a westward-directed plume with generally lower transport speeds as in exercise 7. Results from SRTC show a southward-directed plume into the Mediterranean Sea not predicted by most other models. Finally, another release from the Slovak Republic (Fig. 11, exercise 9) indicated a bifurcated surface plume. The northern portion traversed westerly through Austria, the Czech Republic, Switzerland, Germany, and northern France, while a second footprint was directed to the southwest over Italy and into the Mediterranean Sea. The southwesterly directed plume results from the initial 12-hour release, while the plume directed across France resulted from a change in local wind patterns to easterly for the second 12-hr release. Again, results from SRTC tend to be further south than other model entries.

For the 'dirty bomb' scenario of Exercises 10 and 11, results are given in Figs. 12 and 13. Simulated results indicate a surface plume traveling east-northeast into the southern Scandinavian region before becoming more east-southeastward through northern Europe and western Russia. The SRTC results tend to reach higher latitudes than the other models. The overall patterns for the two exercises are very similar, as would be expected since the only difference in source conditions is the isotope released. The area covered by $\mathrm{Cs}^{137}$ for the SRTC result (Fig. 12) is larger than that for $\mathrm{Pu}^{241}$ (Fig. 13). This is due to the higher density associated with $\mathrm{Pu}^{241}$. A higher density leads to more deposition of the particles to the surface and less material remaining as atmospheric concentration.

\section{DISCUSSION/CONCLUSION}

A prognostic atmospheric numerical model (RAMS) has been used to create meteorology with more detail than typically available from the national weather services. These data are used in a Lagrangian particle dispersion model to simulate the long-term effects from hypothetical releases in Europe as part of the European Union's ENSEMBLE modeling program. 
Differences between model results stem from the use of different background model physics and numerics, as well as different meteorological input. Most of the European participants use the European Center for Medium Range Weather Forecasts (ECMWF) model for meteorological conditions, while SRTC uses a product generated by NOAA to drive RAMS. A person tasked with giving advice to a decision-maker regarding recommended actions in the event of an atmospheric release would find the plots given in Figs. 3 to 13 valuable, with the knowledge that multiple simulations using different input and/or physical characteristics provide similar results. In other words, the user would have much more confidence in the ensemble of the results as opposed to an individual simulation.

The SRTC results utilize a relatively coarse model grid, which is quite adequate for long term consequences. However, transport analysis very near the source is not expected to be particularly useful. More powerful computing hardware now allows for the use of finer grid resolution than was available to SRTC at the inception of the ENSEMBLE program. Combined with the parallel processing capabilities of a newer version of RAMS, grid resolutions nearly an order of magnitude better than previously utilized are now possible for use in generating detailed meteorology.

Thus, the ENSEMBLE program has been beneficial to the SRTC atmospheric modeling program in several ways. It has enabled the implementation of more complexity in the atmospheric and transport models. The RAMS model has not only been established for simulations in Europe (thus allowing for modeling of a number of potential accident scenarios in this region of the world), it also has been a test-bed for running a parallel version of the numerical model. In addition, running the code in an automated fashion through a series of shell and script commands is valuable to work performed in other areas of operations at the SRS. The transport model has been improved by incorporating dry and wet deposition removal mechanisms. This particular feature was valuable in subsequent development of a version of LPDM for calculating ingestion and dose from a number of isotopes during graded emergency response exercises at the SRS.

The ENSEMBLE program also allows the modeling capabilities at SRTC to be more thoroughly evaluated against other models currently in use. The RAMS model has been evaluated in a number of studies, including comparison with local SRS tower data, and regional NWS surface and upper air observations. However, ENSEMBLE allows for a model inter-comparison not previously performed at offsite locations. Finally, participation in the ENSEMBLE program has provided SRTC scientists the opportunity to network with many European scientists, and to learn more about the modeling program of these different agencies.

Acknowledgement: This work is based on the results obtained within the ENSEMBLE Consortium (http://ensemble.ei.jrc.it) which is acknowledged. ENSEMBLE is a project supported by the European Commission DEG-RES Nuclear Fission Program 


\section{REFERENCES}

Bellasio, R., Bianconi, R., Graziani, G. and Musca, S., 1999: RTMOD: An Internet based system to analyse the predictions of long-range atmospheric dispersion models. Computers and Geosciences, 25 (7), 819-833.

Buckley, R. L., 2000: Modeling atmospheric deposition from a cesium release in Spain using a stochastic transport model. $11^{\text {th }}$ Joint Conference on the Applications of Air Pollution Meteorology with the Air and Waste Management Association, Long Beach, CA, American Meteorological Society, 190-195.

Chen, C., and W. R. Cotton, 1983: A one-dimensional simulation of the stratocumulus-capped mixed layer. B. Layer Meteor., 25, 289-321.

Davies, H. C., 1976: A lateral boundary formulation for multi-level prediction models. Quart. J. Roy. Met. Soc., 102, 405-418.

Dickinson, R. E., A. Henderson-Sellers, P. J. Kennedy, and M. F. Wilson, 1986: BiosphereAtmosphere Transfer Scheme (BATS) for the NCAR Community Climate Model. National Center for Atmospheric Research, Tech. Note NCAR/TN-275+ST, 69 pp. [Available from NCAR, P.O. Box 3000, Boulder, CO 80307].

Galmarini, S., R. Bianconi, R. Bellasio, G. Graziani, 2001: Forecasting the consequences of accidental releases of radionuclides in the atmosphere from ensemble dispersion modelling. J. Environ. Radioactivity, 57, 203-219.

Gifford, F. A. (1982): Horizontal diffusion in the atmosphere: a Lagrangian-dynamical theory. Atmos. Environ., 16, 505-512.

Girardi, F., G. Graziani, D. van Velzen, S. Galmarini, S. Mosca, R. Bianconi, R. Bellasio, W. Klug, and G. Fraser (Eds), 1998: ETEX, The European Tracer Experiment. Joint Research Centre, European Commission, Italy.

Helfand, H. M., and J. C. Labraga, 1988: Design of a nonsingular level 2.5 second-order closure model for the prediction of atmospheric turbulence. J. Atmos. Sci., 45, 113-132.

Hunter, C. H., 1990: Weather Information and Display (WIND) System User's Manual. WSRCTM-90-14, Savannah River Site, Aiken SC, 29808.

Klug, W., G. Graziani, G. Grippa, D. Pierce, and C. Tassone (Eds), 1992: Evaluation of long range atmospheric transport models using environmental radioactivity data from the Chernobyl accident. The ATMES Report. Elsevier Science Publishers, Linton Rd., Essex, England. 
Kuo, H. L., 1974: Further studies of the parameterization of the influence of cumulus convection on large-scale flow. J. Atmos. Sci., 31, 1232-1240.

McCumber, M. C., and R. A. Pielke, 1981: Simulation of the effects of surface fluxes of heat and moisture in a mesoscale numerical model: I. Soil layer. J. Geophys. Res. 86 (C10), 99299938.

McNider, R. T., M. D. Moran, and R. A. Pielke, 1988: Influence of diurnal and inertial boundary-layer oscillations on long-range dispersion. Atmos. Environ., 22, 2445-2462.

Mellor, G. L. and T. Yamada, 1982: Development of a turbulent closure model for geophysical fluid problems. Rev. Geophys. Space Phys. 20 (10), 851-875.

Pielke, R. A., W. R. Cotton, R. L. Walko, C. J. Tremback, W. A. Lyons, L. D. Grasso, M. E. Nicholls, M. D. Moran, D. A. Wesley, T. J. Lee, and J. H. Copeland, 1992: A comprehensive meteorological modeling system--RAMS. Meteor. Atmos. Phys., 49, 69-91.

Tremback, C. J., 1990: Numerical simulation of a mesoscale convective complex: Model development and numerical results. Ph.D. dissertation, available from Colorado State University, $247 \mathrm{pp}$.

Tremback, C. J. and R. Kessler, 1985: A surface temperature and moisture parameterization for use in mesoscale numerical models. Preprints, Seventh Conf. on Numerical Weather Prediction, Montreal, Quebec, Canada, American Meteorological Society, 355-358.

Uliasz, M., 1993: The atmospheric mesoscale dispersion modeling system. J. Appl. Meteor., 32, 139-149.

Warner, T. T., R. A. Peterson, and R. E. Treadon, 1997: A tutorial on lateral boundary conditions as a basic and potentially serious limitation to regional numerical weather prediction. Bull. Amer. Meteor. Soc., 78, 2599-2617. 
WSRC-TR-2003-00279

July 2003

Table 1: ENSEMBLE Participating Agencies

\begin{tabular}{|c|c|l|c|}
\hline $\begin{array}{c}\text { Agency } \\
\text { ID }\end{array}$ & $\begin{array}{c}\text { Model } \\
\text { Code }\end{array}$ & \multicolumn{1}{|c|}{ Agency } & Country \\
\hline 01 & UK1 & Met Office & United Kingdom \\
\hline 02 & DK1 & Risø National Laboratory & Denmark \\
\hline 03 & SE1 & Swedish Meteorological and Hydrological Institute & Sweden \\
\hline 04 & DE1 & Deutscher Wetterdienst & Germany \\
\hline 05 & FR1 & Meteo-France & France \\
\hline 06 & AT1 & Central Institute for Meteorology and Geodynamics & Austria \\
\hline 07 & GR1 & National Centre for Scientific Research “Demokritos" & Germany \\
\hline 08 & NL1 & National Institute of Public Health and the Environment & The Netherlands \\
\hline 09 & NO1 & Norwegian Meteorological Institute & Norway \\
\hline 10 & PL1 & Institute of Atomic Energy & Poland \\
\hline 11 & DK2 & Danish Meteorological Institute & Denmark \\
\hline 12 & BE1 & Royal Meteorological Institute Belgium & Belgium \\
\hline 13 & NL2 & Royal Netherlands Meteorological Institute & Finland \\
\hline 14 & FI1 ${ }^{(2)}$ & Finnish Meteorological Institute & United States \\
\hline 15 & US1 & Savannah River Technology Center & Canada \\
\hline 16 & CA1 & Environment Canada & Denmark \\
\hline 21 & DK3 & Danish Meteorological Institute & Denmark \\
\hline 22 & DK4 & Risø National Laboratory & Germany \\
\hline 23 & GR2 ${ }^{(5)}$ & National Centre for Scientific Research “Demokritos" & Germany \\
\hline 24 & DE2 & Deutscher Wetterdienst & France \\
\hline 25 & FR2 & Meteo-France & Central Institute for Meteorology and Geodynamics \\
\hline 26 & AT2 & Baria \\
\hline 27 & BG1 & National Institute of Meteorology and Hydrology & \\
\hline
\end{tabular}

${ }^{(2)}:$ Began participation in $2^{\text {nd }}$ exercise

${ }^{(4)}$ : Began participation in $4^{\text {th }}$ exercise

${ }^{(5)}$ : Began participation in $5^{\text {th }}$ exercise 
WSRC-TR-2003-00279

July 2003

Table 2: RAMS Input Characteristics

Spatial and Temporal Characteristics

\begin{tabular}{|l|c|l|c|}
\hline Simulation Time & $84 \mathrm{hr}$ & Timestep & $60 \mathrm{~s}$ \\
\hline Horizontal Grid Points $(x, y)$ & $88 \times 72$ & Grid Spacing & $75 \mathrm{~km}$ \\
\hline Vertical Grid Points & 33 & Model Top & $18129 \mathrm{~m}$ \\
\hline Vertical Spacing: Surface & $60 \mathrm{~m}$ & Vertical Spacing: Top & $1000 \mathrm{~m}$ \\
\hline Pole Latitude & $52.5^{\circ} \mathrm{N}$ & Pole Longitude & $22.0^{\circ} \mathrm{E}$ \\
\hline \multicolumn{3}{|c|}{ Surface Input } \\
\hline Topography & $10^{\prime}$ USGS \\
\hline Vegetation & Global 1 ${ }^{\circ}$, BATS categories \\
\hline Sea Surface Temperature & Global 1 ${ }^{\circ}$ updated monthly \\
\hline $\begin{array}{l}\text { Lateral Boundary Condition } \\
\text { Radiation (short, long) }\end{array}$ & Davies relaxation (1976) toward large scale; $f=600 \mathrm{~s}$ \\
\hline Convective Parameterization & Chen and Cotton (1983); $f=1800 \mathrm{~s}$ \\
\hline Turbulence Parameterization & Modified Kuo cumulus (Tremback 1990); $f=1800 \mathrm{~s}$ \\
\hline
\end{tabular}


Table 3: Summary of the ENSEMBLE Scenarios with Details on the Source

\begin{tabular}{|c|c|c|c|c|c|c|c|c|}
\hline$\#$ & Location & $\begin{array}{l}\text { Lat } \\
\left({ }^{\circ} \mathrm{N}\right)\end{array}$ & $\begin{array}{l}\text { Lon } \\
\left({ }^{\circ} \mathrm{E}\right)\end{array}$ & $\begin{array}{l}\text { Release } \\
\text { Time }\end{array}$ & $\begin{array}{l}\text { Dur } \\
\text { (hr) }\end{array}$ & $\begin{array}{c}\text { Rate } \\
\left(\mathrm{Bq} \mathrm{hr}^{-1}\right)\end{array}$ & $\begin{array}{c}\text { Height } \\
\text { (m AGL) }\end{array}$ & $\begin{array}{c}\text { Horizon } \\
\text { Time }\end{array}$ \\
\hline 1 & $\begin{array}{c}\text { Lerwick, } \\
\text { Shetland Isles }\end{array}$ & 60.15 & -1.17 & $\begin{array}{l}1200 \text { UTC } \\
18 \text { Apr. } 2001\end{array}$ & 6 & $10^{15}$ & 0 & $\begin{array}{c}0000 \text { UTC } \\
21 \text { Apr. } 2001\end{array}$ \\
\hline 2 & $\begin{array}{c}\text { Carcassonne, } \\
\text { France }\end{array}$ & 43.22 & 2.33 & $\begin{array}{c}1200 \text { UTC } \\
28 \text { Sep. } 2001\end{array}$ & 6 & $10^{15}$ & 300 & $\begin{array}{c}0000 \text { UTC } \\
01 \text { Oct. } 2001\end{array}$ \\
\hline 3 & $\begin{array}{l}\text { London, } \\
\text { England }\end{array}$ & 51.55 & 0.00 & $\begin{array}{c}1200 \text { UTC } \\
21 \text { Nov. } 2001\end{array}$ & 6 & $10^{15}$ & 0 & $\begin{array}{c}0000 \text { UTC } \\
24 \text { Nov. } 2001\end{array}$ \\
\hline 4 & $\begin{array}{l}\text { Nantes, } \\
\text { France }\end{array}$ & 47.22 & -1.55 & $\begin{array}{l}1145 \text { UTC } \\
05 \text { Feb. } 2002\end{array}$ & 6 & $*$ & 0 to 1300 & $\begin{array}{c}2100 \text { UTC } \\
07 \text { Feb. } 2002\end{array}$ \\
\hline 5 & $\begin{array}{c}\text { Stockholm, } \\
\text { Sweden }\end{array}$ & 59.33 & 18.07 & $\begin{array}{c}1200 \text { UTC } \\
16 \text { Apr. } 2002\end{array}$ & $7^{\S}$ & $\S$ & 2 & $\begin{array}{c}0000 \text { UTC } \\
19 \text { Apr. } 2002\end{array}$ \\
\hline 6 & $\begin{array}{l}\text { Dublin, } \\
\text { Ireland }\end{array}$ & 53.87 & -6.27 & $\begin{array}{c}1200 \text { UTC } \\
25 \text { Jun. } 2002\end{array}$ & 15 & $10^{16}$ & 0 & $\begin{array}{c}0000 \text { UTC } \\
\text { 28 Jun. } 2002\end{array}$ \\
\hline 7 & $\begin{array}{l}\text { Glasgow, } \\
\text { Scotland }\end{array}$ & 55.88 & -4.23 & $\begin{array}{c}0700 \text { UTC } \\
04 \text { Oct. } 2002\end{array}$ & 4 & $10^{15}$ & 0 to 500 & $\begin{array}{c}1800 \text { UTC } \\
06 \text { Oct. } 2002\end{array}$ \\
\hline 8 & $\begin{array}{c}\text { Mochovche, } \\
\text { Slovakia }\end{array}$ & 48.27 & 18.47 & $\begin{array}{c}1200 \text { UTC } \\
03 \text { Dec. } 2002\end{array}$ & 12 & $F$ & 25 & $\begin{array}{c}0000 \text { UTC } \\
06 \text { Dec. } 2002\end{array}$ \\
\hline 9 & $\begin{array}{c}\text { Bratislava, } \\
\text { Slovakia }\end{array}$ & 48.15 & 17.13 & $\begin{array}{c}1200 \text { UTC } \\
12 \text { Feb. } 2003\end{array}$ & $24^{\dagger}$ & $10^{16}$ & 25 & $\begin{array}{c}0000 \text { UTC } \\
15 \text { Feb. } 2003\end{array}$ \\
\hline 10 & $\begin{array}{l}\text { London, } \\
\text { England }\end{array}$ & 51.55 & 0.00 & $\begin{array}{l}1200 \text { UTC } \\
11 \text { Jun. } 2003\end{array}$ & 0.25 & $10^{13}$ & 350 & $\begin{array}{c}0000 \text { UTC } \\
14 \text { Jun. } 2003\end{array}$ \\
\hline $\begin{array}{c}11 \\
\varnothing\end{array}$ & $\begin{array}{l}\text { London, } \\
\text { England }\end{array}$ & 51.55 & 0.00 & $\begin{array}{l}1200 \text { UTC } \\
11 \text { Jun. } 2003\end{array}$ & 0.25 & $9.94 \times 10^{12}$ & 350 & $\begin{array}{c}0000 \text { UTC } \\
14 \text { Jun. } 2003\end{array}$ \\
\hline
\end{tabular}

*Emission throughout the vertical (uniform) from 0 to $1300 \mathrm{~m} \mathrm{AGL.}$

$0.9 \times 10^{15} \mathrm{~Bq} \mathrm{hr} r^{-1}$ from 0 to $1000 \mathrm{~m} \mathrm{AGL}$

$0.1 \times 10^{15} \mathrm{~Bq} \mathrm{hr} r^{-1}$ from 1000 to $1300 \mathrm{~m} \mathrm{AGL}$

${ }^{\S}$ Emission varied with time as follows:

$1.0 \times 10^{15} \mathrm{~Bq} \mathrm{hr} r^{-1}$ from 1200 to 1400 UTC

$1.5 \times 10^{15} \mathrm{~Bq} \mathrm{hr} r^{-1}$ from 1600 to 1900 UTC

$1.0 \times 10^{15} \mathrm{~Bq} \mathrm{hr} r^{-1}$ from 2000 to 2200 UTC

${ }^{\ddagger}$ Emission varied with time as follows:

$2.54 \times 10^{14} \mathrm{~Bq} \mathrm{hr} r^{-1}$ from 1200 to 1300 UTC

$4.32 \times 10^{12} \mathrm{~Bq} \mathrm{hr} r^{-1}$ from 1600 to 1900 UTC

$8.61 \times 10^{13} \mathrm{~Bq} \mathrm{hr} r^{-1}$ from 1300 to 1400 UTC $1.28 \times 10^{12} \mathrm{~Bq} \mathrm{hr} \mathrm{r}^{-1}$ from 1900 to 2000 UTC

$5.05 \times 10^{13} \mathrm{~Bq} \mathrm{hr} \mathrm{r}^{-1}$ from 1400 to 1500 UTC $2.22 \times 10^{11} \mathrm{~Bq} \mathrm{hr} r^{-1}$ from 2000 to 2300 UTC

$8.56 \times 10^{12} \mathrm{~Bq} \mathrm{hr} r^{-1}$ from 1500 to 1600 UTC

${ }^{\dagger}$ Emission varied with time as follows:

$1.0 \times 10^{16} \mathrm{~Bq} \mathrm{hr} r^{-1}$ from 1200 to 2359 UTC $12 \mathrm{Feb}$

$1.0 \times 10^{16} \mathrm{~Bq} \mathrm{hr} r^{-1}$ from 0800 to 1959 UTC $13 \mathrm{Feb}$

${ }^{\varnothing}$ This source is $\mathrm{Pu}{ }^{241}$ rather than $\mathrm{Cs}^{137}$. 
Table 4: Timing of ENSEMBLE Exercises at SRTC

\begin{tabular}{|c|c|c|c|c|}
\hline$\#$ & $\begin{array}{c}\text { Time from Release }^{a} \\
\text { (HH:MM) }\end{array}$ & $\begin{array}{c}\text { Email Time }^{b} \\
\text { (LST) }\end{array}$ & $\begin{array}{c}\text { User Time }^{c} \\
\text { (LST) }\end{array}$ & $\begin{array}{c}\text { Upload Time }^{d} \\
\text { (LST) }\end{array}$ \\
\hline 1 & $+4: 18$ & $04: 08$ & $07: 15$ & $12: 18$ \\
\hline 2 & $+1: 38$ & $04: 22$ & $06: 30$ & $09: 38$ \\
\hline 3 & $+1: 14$ & $04: 02$ & $06: 00$ & $08: 14$ \\
\hline 4 & $+4: 25$ & $05: 26$ & $06: 00$ & $11: 10$ \\
\hline 5 & $-0: 37$ & $06: 22$ & $06: 24$ & $07: 23$ \\
\hline 6 & $+1: 01$ & $05: 02$ & $06: 10$ & $09: 01$ \\
\hline 7 & $+4: 10$ & $03: 39$ & $06: 10$ & $07: 10$ \\
\hline 8 & $+0: 42$ & $05: 24$ & $05: 45$ & $07: 42$ \\
\hline 9 & $-0: 54$ & $05: 38$ & $05: 30$ & $06: 06$ \\
\hline 10 & $-0: 18$ & $04: 11$ & $07: 05$ & $07: 42$ \\
\hline $11^{\dagger}$ & $+0: 47$ & $04: 11$ & $07: 05$ & $08: 47^{\dagger}$ \\
\hline
\end{tabular}

a: Time of upload relative to the hypothetical initial release time. Positive numbers denote times after the release, and negative numbers denote times before the release (in hours and minutes).

$b$ : Local time in which the email message from ENSEMBLE was received at SRTC.

$c$ : Local time in which the modeler actually read the message.

$d$ : Local time in which results were uploaded to the ENSEMBLE web page.

$\dagger$ : Difficulties in transmission of formatted results led to a delay in the final uploaded results of one hour for this exercise. 


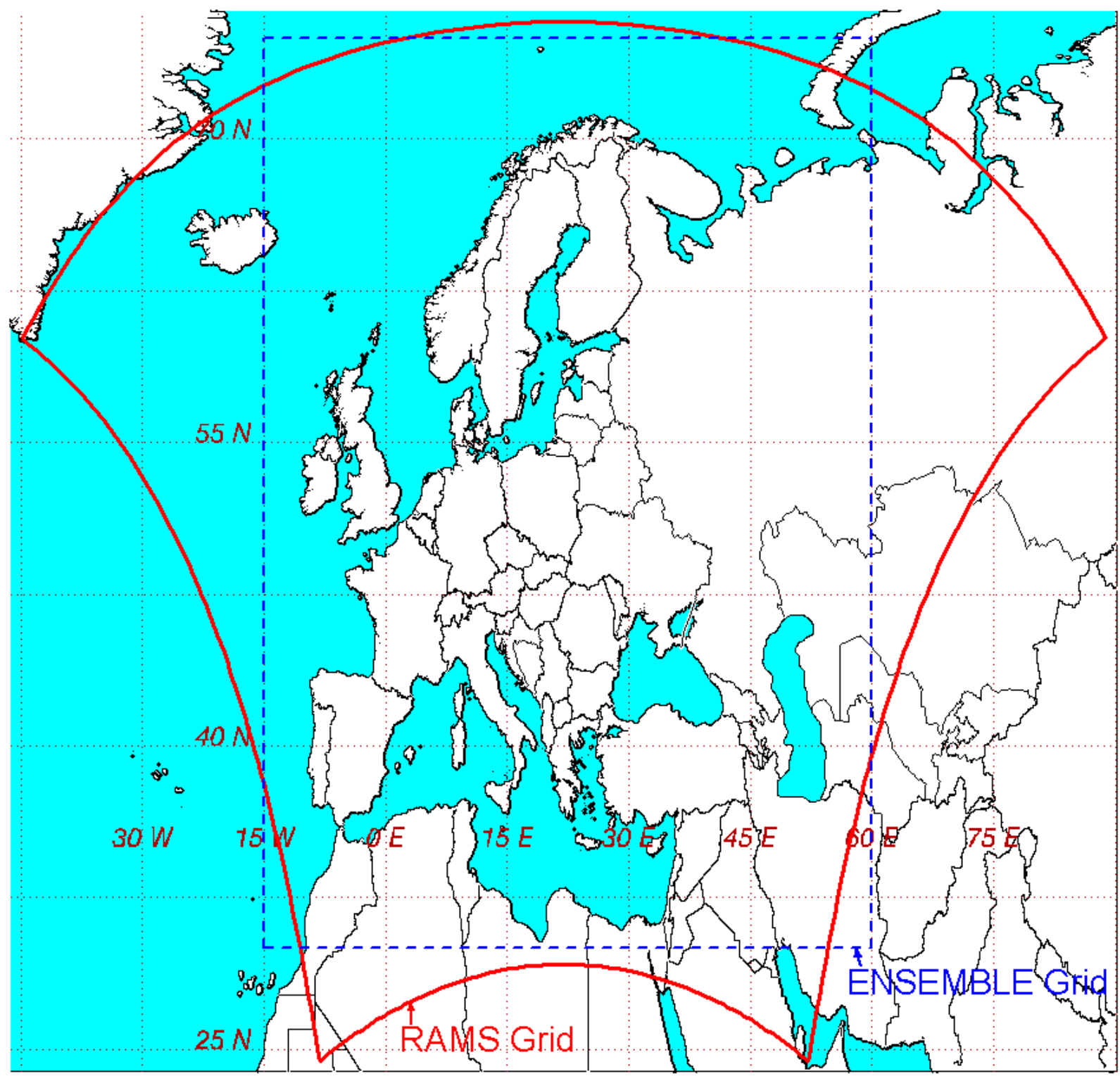

Figure 1: Boundaries of the grids utilized in this study. The ENSEMBLE grid is spaced at regular latitude and longitude intervals, with results required at $0.5^{\circ}$ intervals, while the RAMS grid is polar-stereographic. 


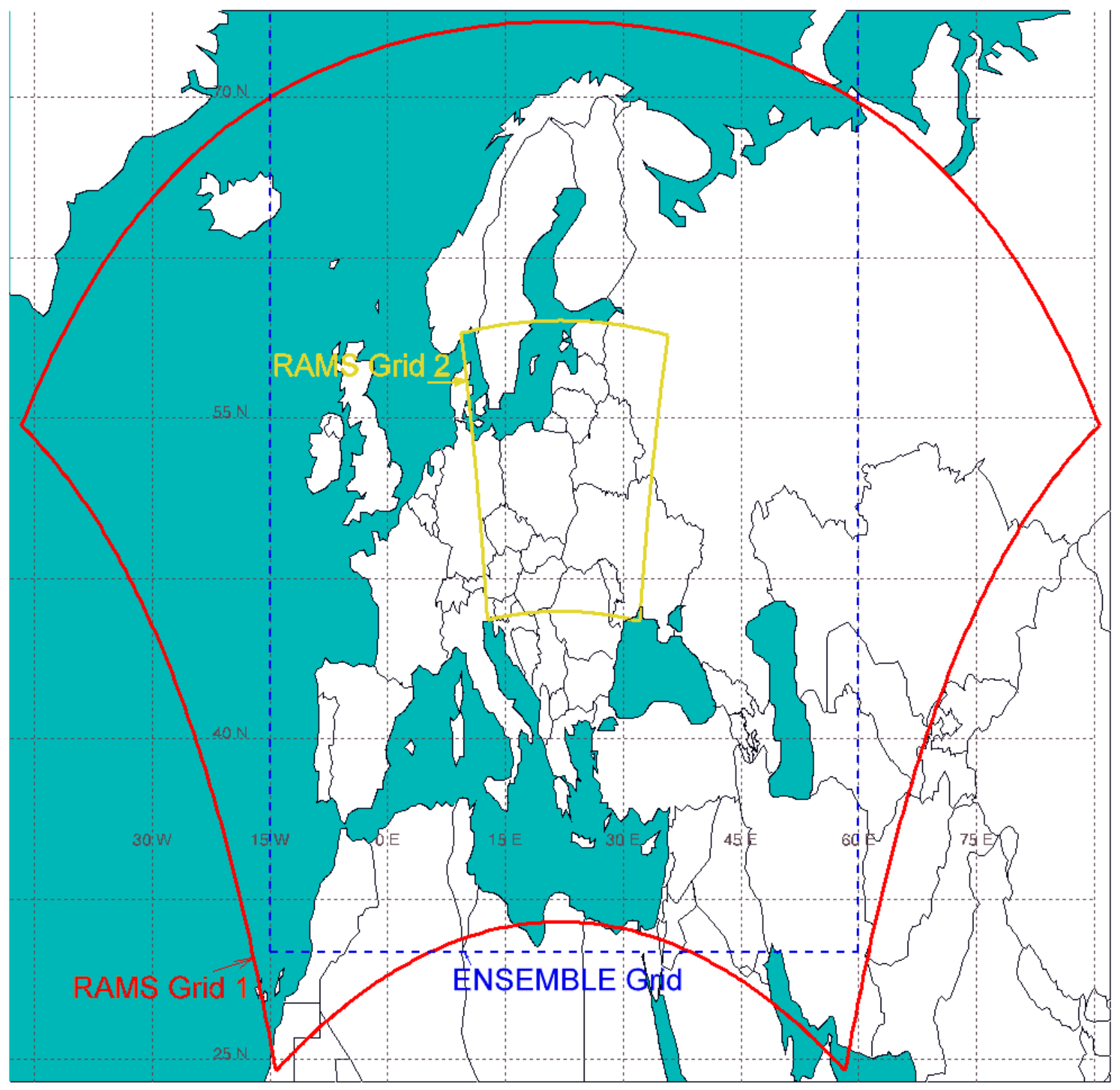

Figure 2: Boundaries of a potential multi-grid study where the inner and outer grid have the same central point. The ENSEMBLE grid is spaced at regular latitude and longitude intervals, with results required at $0.5^{\circ}$ intervals, while the RAMS grids are polar-stereographic. 
WSRC-TR-2003-00279

July 2003

Exercise 01 - Agreement on threshold level for time-integrated concentration of Cs137 Date and time: 2001-04-21 00:00 UTC (+60h0m after relecse start)

Threshold level $=1 \mathrm{Bqh} / \mathrm{m}^{3}$
Release from Lerwick (UK) Location: 01:10 W 60:09 N Start: 2001-04-18 12:00 UTO Duration: 6 hours

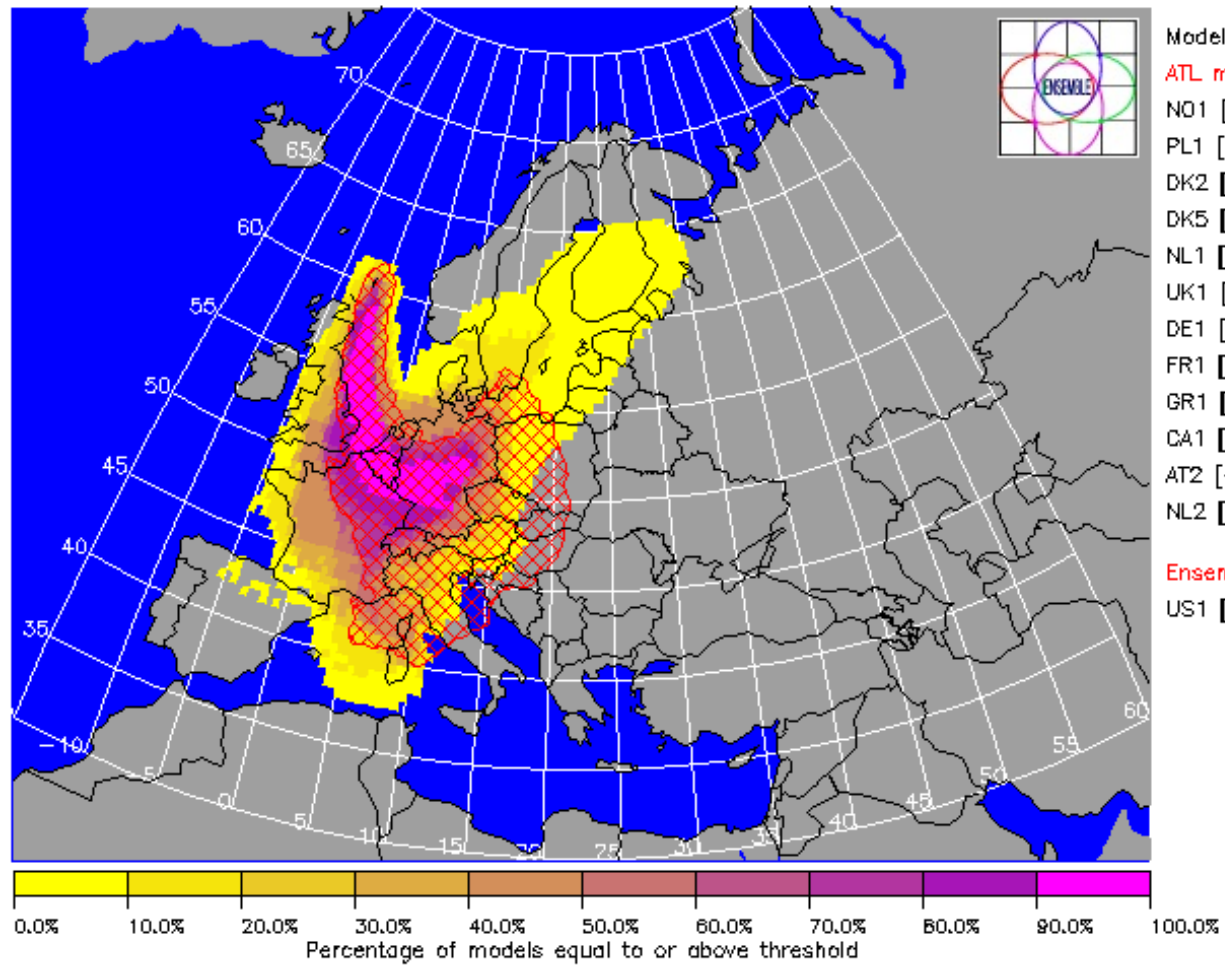

Model(s) [delta meteo/delta upload]

members:

$01[+0 \mathrm{hOm} /+4368 \mathrm{~h} 13 \mathrm{~m}]$

LL1 [+OhOm/ $+220 h 42 \mathrm{~m}]$

DK2 $\left[+0 h_{10 m} 0 \mathrm{H}+423 \mathrm{~m}\right]$

DK5 $[+0 h 0 m /+2 h 3 m]$

NL $1[-6 h 0 m /+44 h 36 m]$

KK1 $[-12 \mathrm{~h} 0 \mathrm{~m} /+11067 \mathrm{~h} 46 \mathrm{~m}]$

DE1 $[-12 \mathrm{~h} 0 \mathrm{~m} /-2 \mathrm{~h} 4 \mathrm{~m}]$

R1 $[-12 \mathrm{hOm} /+3405 \mathrm{~h} 11 \mathrm{~m}]$

R $1[-12 \mathrm{hDm} /+383 \mathrm{~h} 53 \mathrm{~m}]$

CA. $1[-12 \mathrm{hOm} /-2 \mathrm{~h} 7 \mathrm{~m}]$

T2 $[-12 \mathrm{~h} 0 \mathrm{~m} /+9192 \mathrm{~h} 13 \mathrm{~m}]$

NL2 $[-24 h 0 m /+46 h 1 m]$

Ensemble (crosshatch): none

US1 $[-12 \mathrm{hOm} /+4 \mathrm{~h} 1 \mathrm{Bm}]$

Projection: Lambertizimuthol

Created by user ruckley on 2003-03-04 17:49:09 UTO

Figure 3: Experiment 1 Results: Release from Lerwick, Shetland Isles on 18 April, 2001. 
WSRC-TR-2003-00279

July 2003

Exercise 02 - Agreement on threshold level for time-integrated concentration of Cs137 Date and time: 2001-10-01 00:00 UTC (+60h0m after reledse start)

Threshold level $=1.0 \mathrm{Bqh} / \mathrm{m}^{\mathrm{s}}$

Release from Carcossonne $(F)$ Location: 02:20 E 43:13 N Start: 2001-09-28 12:00 UTO Duration: 6 hours

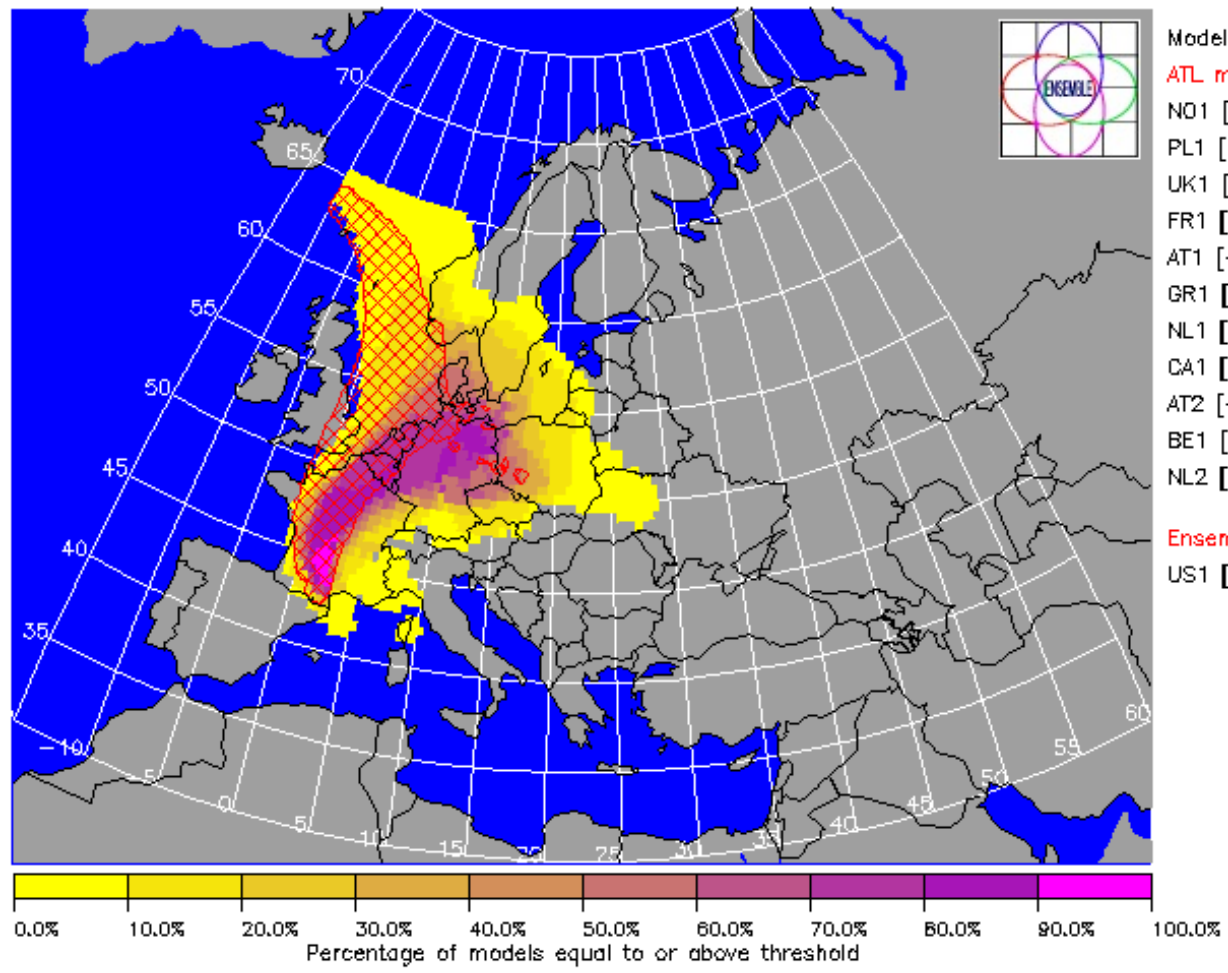

(s) [delta meteo/delta uplood]

members:

$\mathrm{NO} 1[+\mathrm{OhOm} /+456 \mathrm{~h} 9 \mathrm{~m}]$

PL1 [+OhOm/+68h22m]

UK1 $[-12 \mathrm{~h} 0 \mathrm{~m} /+7174 \mathrm{~h} 34 \mathrm{~m}]$

FR1 $[-12 \mathrm{~h} 0 \mathrm{~m} /-2 \mathrm{~h} 46 \mathrm{~m}]$

T1 $[-12 \mathrm{~h} 0 \mathrm{~m} /-2 \mathrm{~h} 42 \mathrm{~m}]$

RR1 $[-12 \mathrm{hOm} /+48 \mathrm{~h} 54 \mathrm{~m}]$

NL1 $[-12 \mathrm{hOm} /-2 \mathrm{~h} 46 \mathrm{~m}]$

A.1 $[-12 \mathrm{hOm} /-1 \mathrm{~h} 44 \mathrm{~m}]$

AT2 $[-12 \mathrm{~h} 0 \mathrm{~m} /+5297 \mathrm{~h} 56 \mathrm{~m}]$

BE1 $[-24 h 0 \mathrm{~m} /+190 \mathrm{~h} 33 \mathrm{~m}]$

NL2 $[-24 h 0 \mathrm{~m} /+144 \mathrm{~h} 27 \mathrm{~m}]$

Ensemble (crosshatch): none

US1 $[-12 \mathrm{hOm} /+1 \mathrm{~h} 38 \mathrm{~m}]$

Projection: Lambertezimuthol

Created by user ruckley on 2003-03-04 17:31:31 UTO

Figure 4: Experiment 2 Results: Release from Carcassonne, France on 28 September, 2001. 
WSRC-TR-2003-00279

July 2003

Exercise 03 - Agreement on threshold level for time-integrated concentration of Cs137 Date and time: 2001-11-24 00:00 UTC (+60h0m after release start)

Threshold level $=1.0 \mathrm{Bqh} / \mathrm{m}^{\mathrm{s}}$

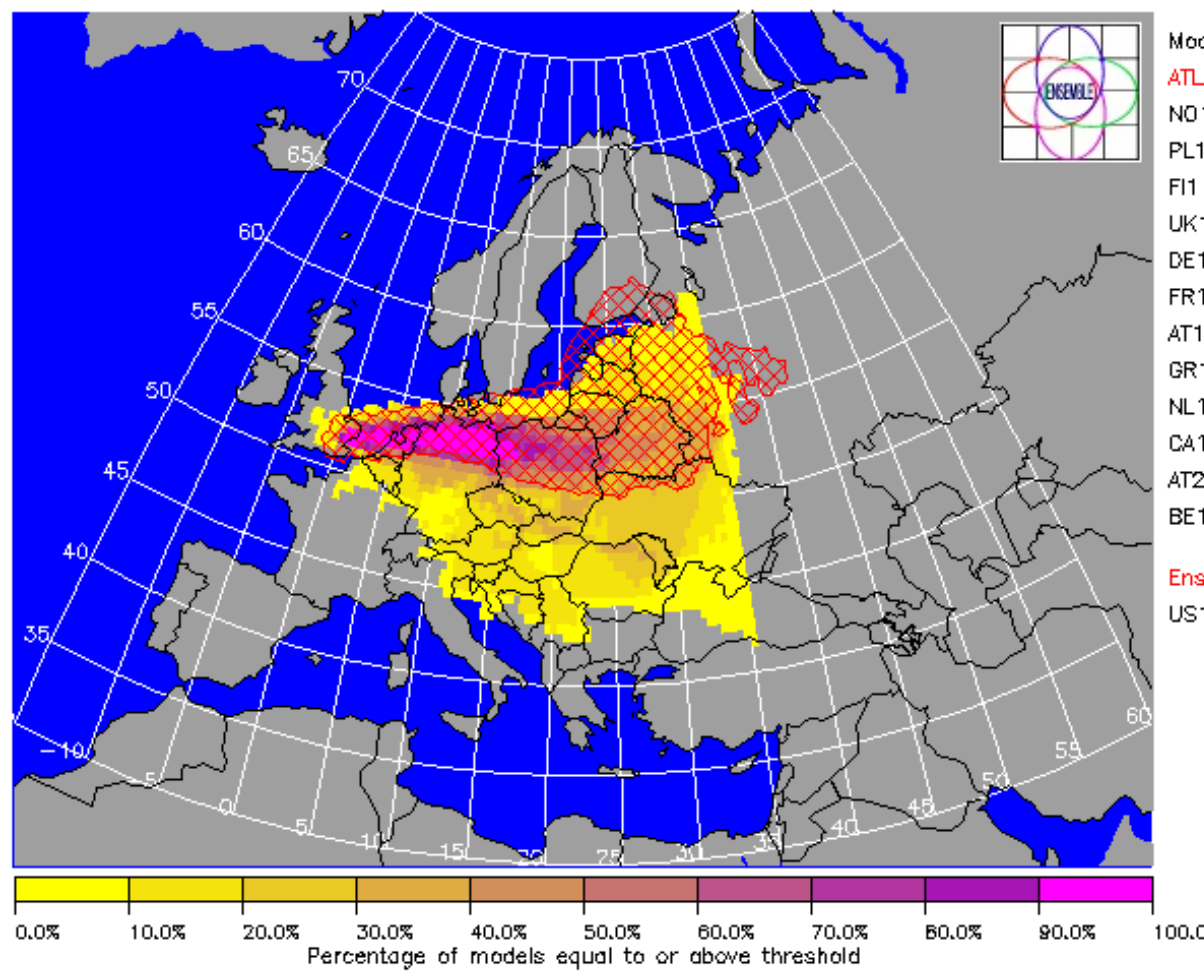

Projection: Lambertezimutha

Created by user ruckley on 2003-03-04 17:33:16 UTO

Figure 5: Experiment 3 Results: Release from London, England on 21 November, 2001.

Release from London (UK) Location: 00:00 E $51: 33 \mathrm{~N}$ Duration: 6 hours members:

$\mathrm{NO} 1[+\mathrm{OhOm} /+\mathrm{Bh} 15 \mathrm{~m}]$ PL1 [+OhOm/+21h16m] FI1 $[-6 h 0 m /+119 h 58 m]$ UK1 $[-12 \mathrm{~h} 0 \mathrm{~m} /+5878 \mathrm{~h} 54 \mathrm{~m}]$ DE1 $[-12 \mathrm{~h} 0 \mathrm{~m} /-1 \mathrm{~h} 50 \mathrm{~m}]$ FR1 $[-12 \mathrm{hOm} /-1 \mathrm{~h} 57 \mathrm{~m}]$ AT1 $[-12 \mathrm{~h} 0 \mathrm{~m} /-2 \mathrm{~h} 11 \mathrm{~m}]$ GR1 $[-12 \mathrm{hOm} /+17 \mathrm{~h} 37 \mathrm{~m}]$ $\mathrm{NL} 1[-12 \mathrm{hOm} /-2 \mathrm{~h} 2 \mathrm{Bm}]$ C.1 $[-12 \mathrm{hOm} /-1 \mathrm{~h} 25 \mathrm{~m}]$ T2 $[-12 \mathrm{~h} 0 \mathrm{~m} /+4001 \mathrm{~h} 58 \mathrm{~m}]$ BE1 $[-24 h 0 \mathrm{~m} /+22 \mathrm{~h} 14 \mathrm{~m}]$ us1 $[-12 \mathrm{hOm} /+1 \mathrm{~h} 14 \mathrm{~m}]$

$00.0 \%$ Start: 2001-11-21 12:00 UTO

Model(s) [delta meteo/delta upload] Ensemble (crosshatch): none 
WSRC-TR-2003-00279

July 2003

Exercise 04 - Agreement on threshold level for time-integrated concentration of Cs137 Date and time: 2002-02-07 18:00 UTC (+54h15m after release start)

Threshold level $=1 \mathrm{Bqh} / \mathrm{m}^{3}$
Release from Nantes (F) Location: 01:33 W 47:13 $\mathrm{N}$ Start: 2002-02-05 11:45 UTO Duration: 6 hours

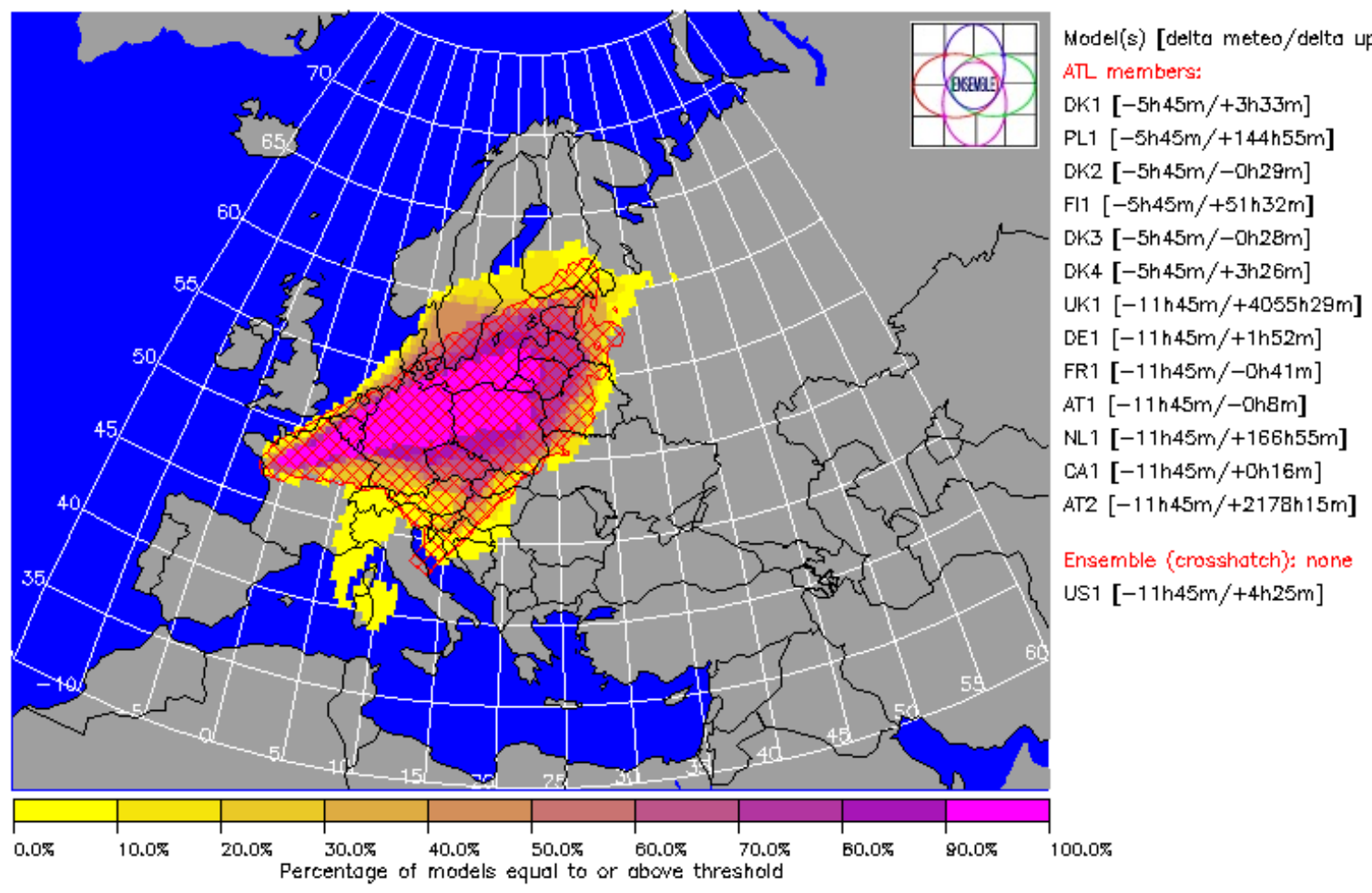

Projection: Lambertezimutha

Created by user rbuckley on 2003-03-17 18:17:56 uTo

Figure 6: Experiment 4 Results: Release from Nantes, France on 5 February, 2002. 
WSRC-TR-2003-00279

July 2003

Exercise 05 - Agreement on threshold level for time-integrated concentration of Cs137 Date and time: 2002-04-19 00:00 UTC (+60h0m after reledse start)

Threshold level $=1.0 \mathrm{Bqh} / \mathrm{m}^{\mathrm{s}}$

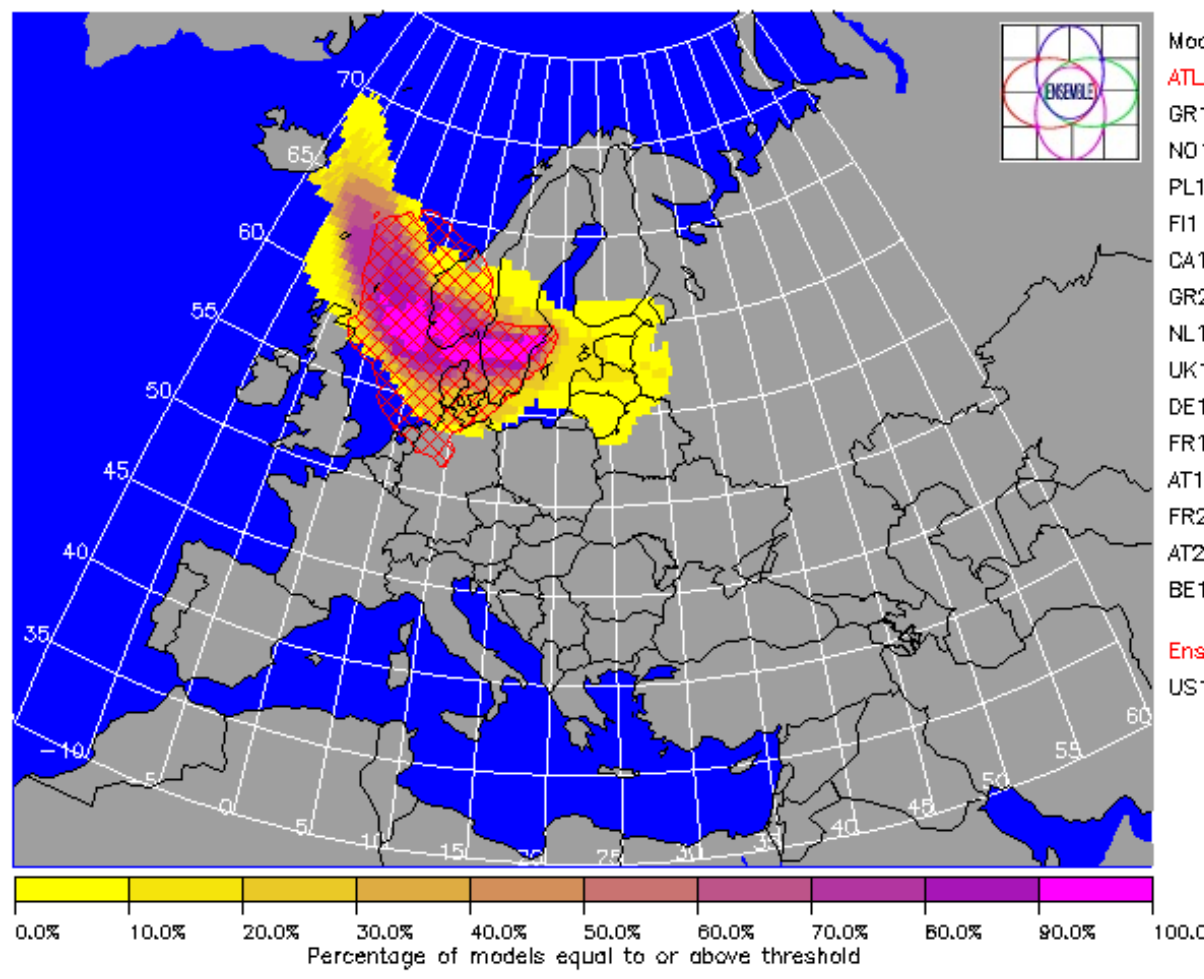

Projection: Lambertizimuthal

Created by user rbuckley on 2003-03-04 17:36:28 UTC

Figure 7: Experiment 5 Results: Release from Stockholm, Sweden on 16 April, 2002.
Release from Stockholm (S) Location: $18: 04$ E 59:20 N Start: 2002-04-16 12:00 UTO Duration: 10 hours

Model(s) [delta meteo/delta upload]

GR1 [+Oh0m/+44h24m] No1 [+OhOm/ $+7 \mathrm{~h} 49 \mathrm{~m}]$ PL1 $\left[+0 h 0 m /+22 h_{13} m_{0}\right]$ Fl1 [+OhOm $/+52 \mathrm{~h} 18 \mathrm{~m}]$ CA1 [+Oh0m/+8h32m] GR2 [+0h0m/+8B7h53m] NL1 [-6h0m/-0h21 m] UK1 $[-12 \mathrm{~h} 0 \mathrm{~m} /+3 \mathrm{~h} 45 \mathrm{~m}]$ DE1 $[-12 \mathrm{~h} 0 \mathrm{~m} /-0 \mathrm{~h} 13 \mathrm{~m}]$ FR1 $[-12 \mathrm{hOm} /-\mathrm{Oh} 29 \mathrm{~m}]$ AT1 $[-12 \mathrm{~h} 0 \mathrm{~m} /-0 \mathrm{~h} 36 \mathrm{~m}]$ $\mathrm{FR} 2[-12 \mathrm{hOm} /+24 \mathrm{~h} 13 \mathrm{~m}]$ AT2 $[-12 \mathrm{~h} 0 \mathrm{~m} /+480 h 11 \mathrm{~m}]$ BE1 $[-24 h 0 \mathrm{~m} /+20 \mathrm{~h} 47 \mathrm{~m}]$ Ensemble (crosshatch): none us1 $[-12 \mathrm{hOm} /-0 \mathrm{~h} 37 \mathrm{~m}]$ 
WSRC-TR-2003-00279

July 2003

Exercise 06 - Agreement on threshold level for time-integrated concentration of Cs137 Date and time: 2002-06-28 00:00 UTC (+60h0m after reledse start)

Threshold level $=1 \mathrm{Bqh} / \mathrm{m}^{3}$
Release from Dublin (IRL) Location: 06:16 W 53:52 N Start: $2002-06-25 \quad 12: 00$ UTO Duration: 15 hours

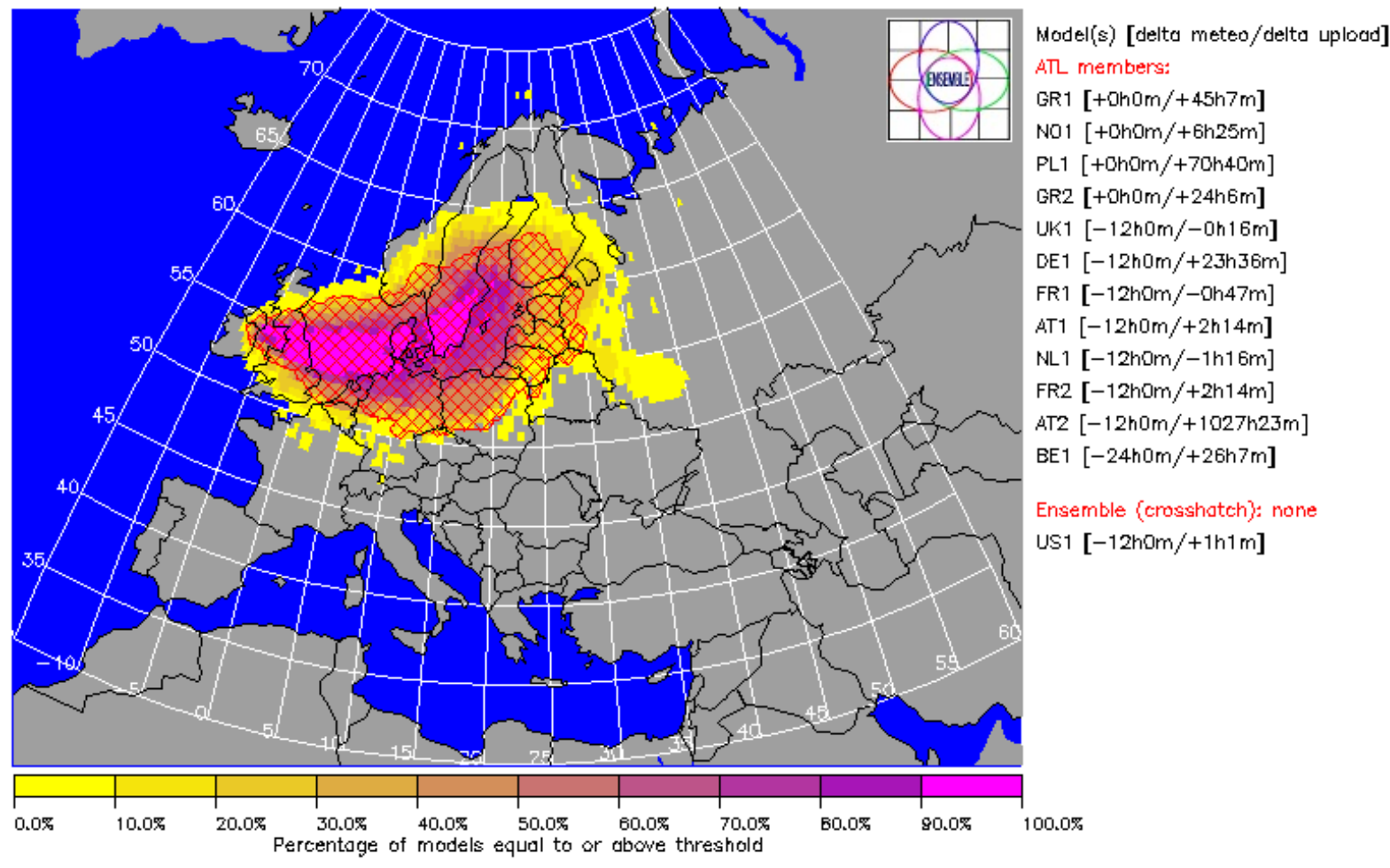

Projection: Lambertizimutha

Created by user rbuckley on 2003-03-04 17:37:54 UTC

Figure 8: Experiment 6 Results: Release from Dublin, Ireland on 25 June, 2002. 
WSRC-TR-2003-00279

July 2003

Exercise 07 - Agreement on threshold level for time-integrated concentration of Cs137 Date and time: 2002-10-06 18:00 UTC ( $+59 \mathrm{hOm}$ after release start)

Threshold level $=1 \mathrm{Bqh} / \mathrm{m}^{3}$
Release from Glosgow Location: 04:14 W 55:53 N Start: $2002-10-0407: 00$ UTO Duration: 4 hours

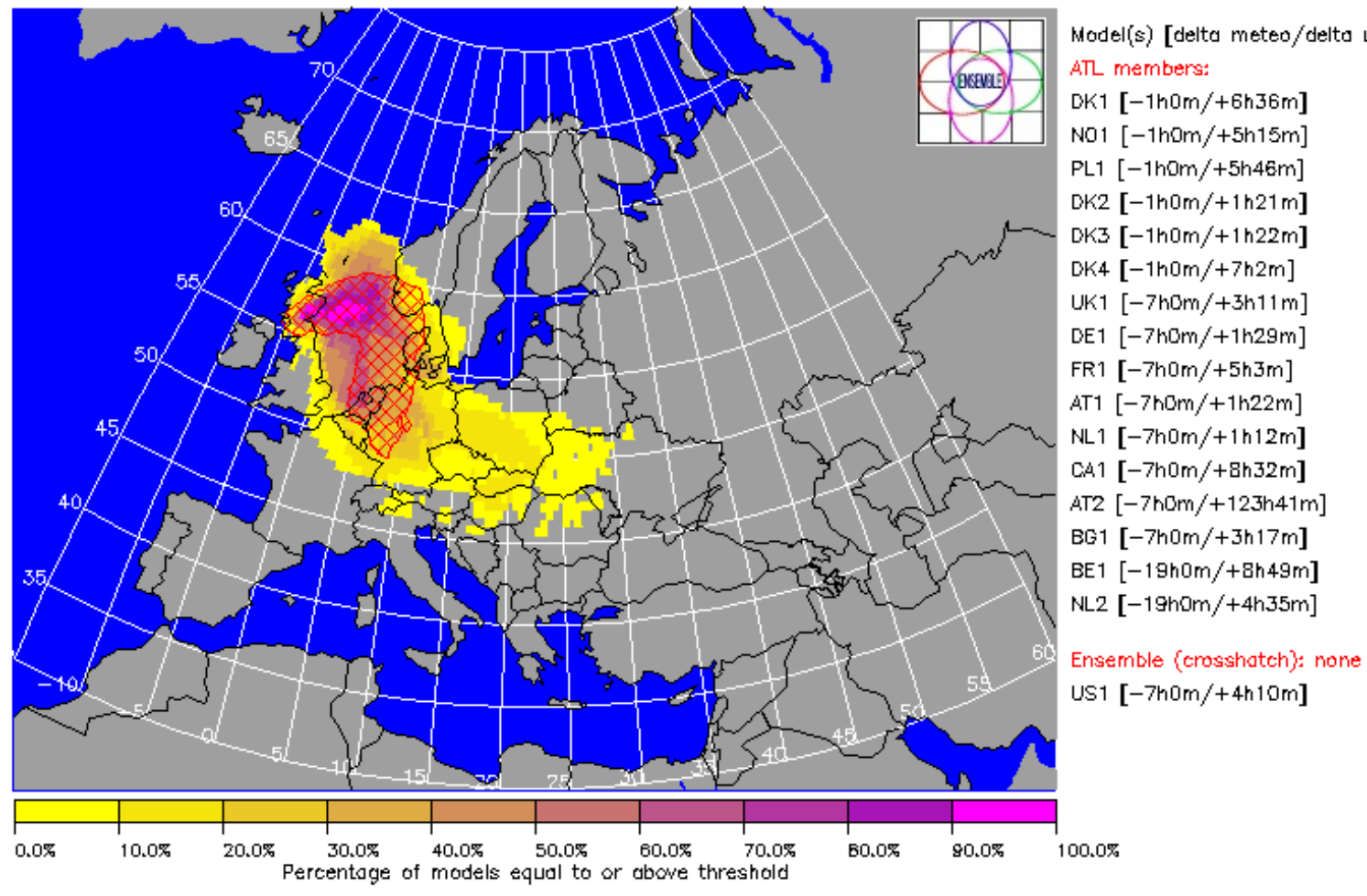

Projection: Lambertezimutha

Created by user rbuckley on 2003-03-04 17:40:14 UTO

Figure 9: Experiment 7 Results: Release from Glasgow, Scotland on 04 October, 2002. 
WSRC-TR-2003-00279

July 2003

Exercise 08 - Agreement on threshold level for time-integrated concentration of Cs137 Date and time: 2002-12-06 00:00 UTC (+60h0m after release start)

Threshold level $=1 \mathrm{Bqh} / \mathrm{m}^{3}$

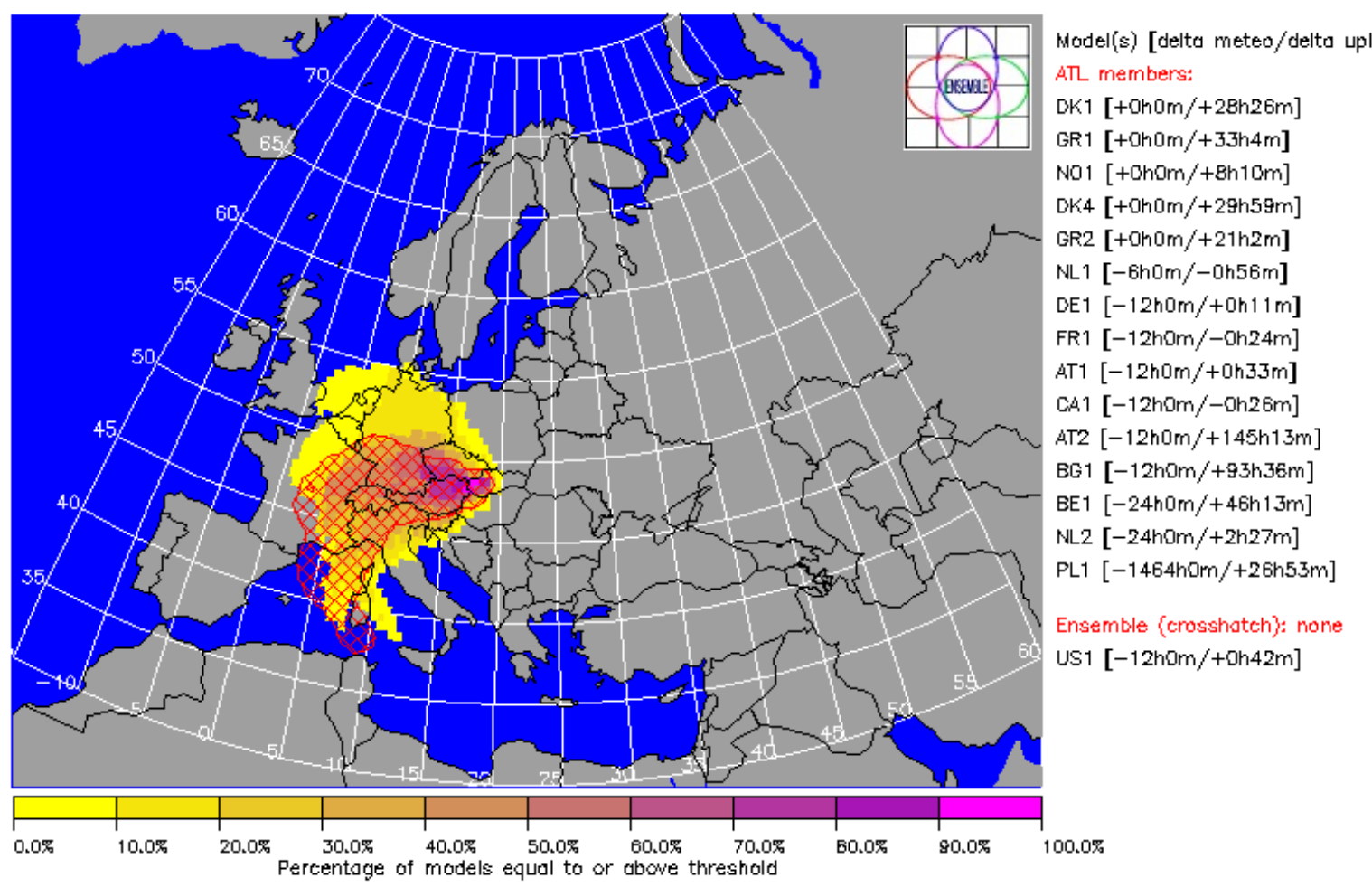

Projection: Lambertizimuthal

Created by user rbuckley on 2003-03-04 17:42:28 UTC

Figure 10: Experiment 8 Results: Release from Mochovche, Slovakia on 03 December, 2002.

DK4 $[+0 h 0 \mathrm{~m} /+29 \mathrm{~h} 59 \mathrm{~m}]$
Release from Mochovce (Slovak Republic) Location: $18: 28 \mathrm{E} 48: 16 \mathrm{~N}$ Start: 2002-12-03 12:00 UTC Duration: 12 hours

Nel(s) [delta meteo/delta upload]

$\mathrm{NO} 1[+\mathrm{OhOm} /+\mathrm{Bh} 10 \mathrm{~m}]$

CA1 $[-12 \mathrm{hOm} /-\mathrm{Dh} 26 \mathrm{~m}]$

$P L 1[-1464 \mathrm{hom} /+26 \mathrm{~h} 5.3 \mathrm{~m}]$

Ensemble \{crosshatch): none

US1 $[-12 \mathrm{hOm} /+0 \mathrm{~h} 42 \mathrm{~m}]$

\section{.}


WSRC-TR-2003-00279

July 2003

Exercise 09 - Agreement on threshold level for time-integrated concentration of Cs137 Date and time: 2003-02-15 00:00 UTC (+60h0m after reledse start)

Threshold level $=1 \mathrm{Bqh} / \mathrm{m}^{3}$

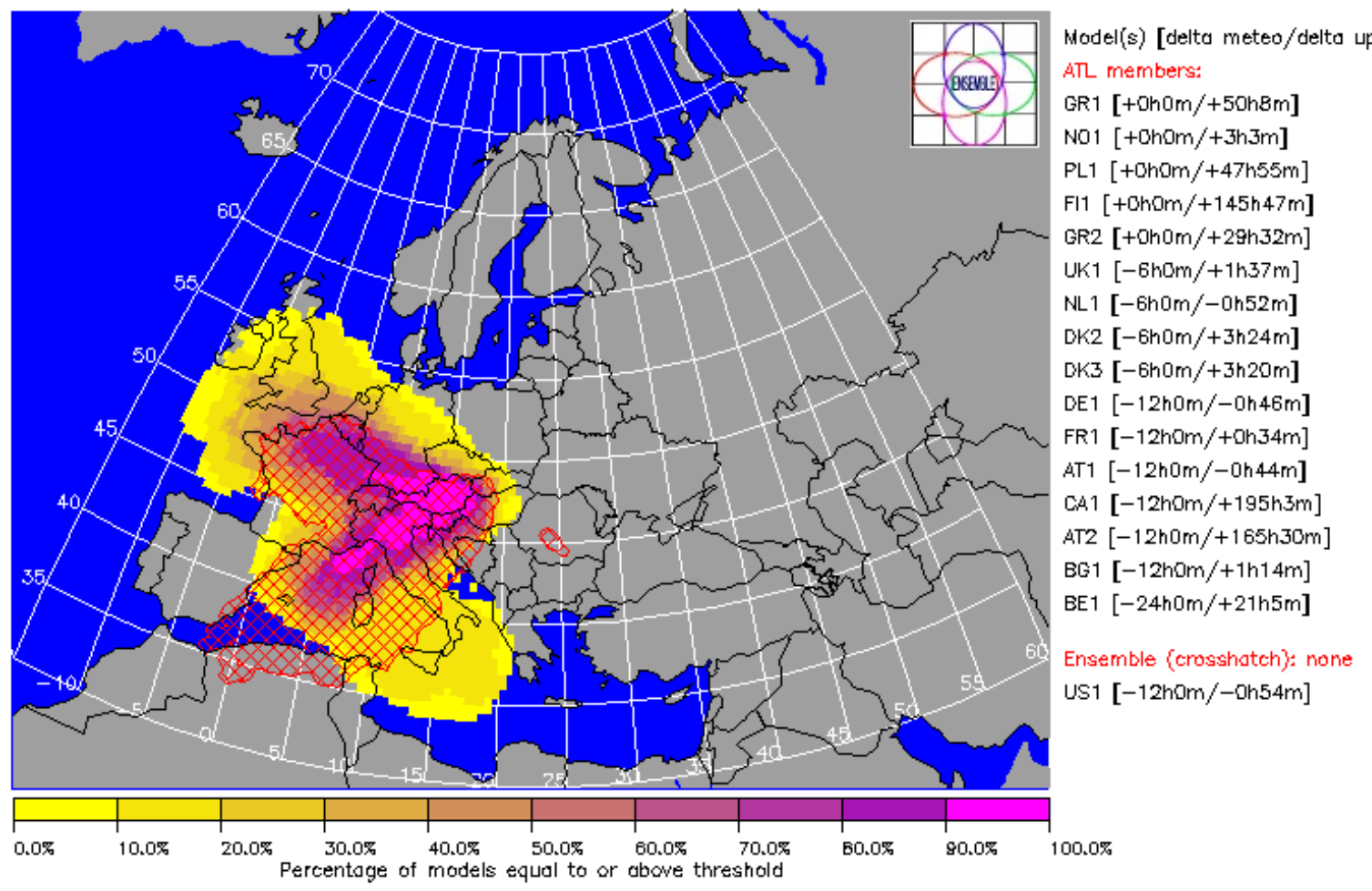

Projection: Lambertizimuthal

Created by user rbuckley on 2003-03-04 17:44:04 UTC

Figure 11: Experiment 9 Results: Release from Bratislava, Slovakia on 12 February, 2003.

Release from Bratislaw (Slowak Rep.) Location: $17: 08 \mathrm{E} \mathrm{48:09 \textrm {N }}$ Start: $2003-02-12$ 12:00 UTO Duration: $12 \mathrm{~h}+12 \mathrm{~h}$ hours

\section{meteo/delta upload]}

GR1 $[+0 h 0 \mathrm{~m} /+50 h 8 \mathrm{~m}]$ NO1 $[+\mathrm{OhOm} /+3 \mathrm{~h} 3 \mathrm{~m}]$ PL1 [+OhOm/+47h55m] Fl1 $[+0 h 0 m /+145 h 47 m]$ [+ DK3 $[-6 h 0 \mathrm{~m} /+3 \mathrm{~h} 20 \mathrm{~m}]$ DE1 $[-12 \mathrm{~h} 0 \mathrm{~m} /-0 \mathrm{~h} 46 \mathrm{~m}]$ FR1 $[-12 \mathrm{hOm} /+0 \mathrm{~h} 34 \mathrm{~m}]$ hom/-0h44m] Ensemble (crosshatch): none US1 $[-12 \mathrm{hOm} /-0 \mathrm{~h} 54 \mathrm{~m}]$ 
Exercise 10 - Agreement on threshold level for time-integrated concentration of Cs137 Date and time: 2003-06-14 00:00 UTC ( $+60 \mathrm{hOm}$ after reledse start)

Threshold level $=0.001 \mathrm{Bgh} / \mathrm{m}^{\mathrm{s}}$

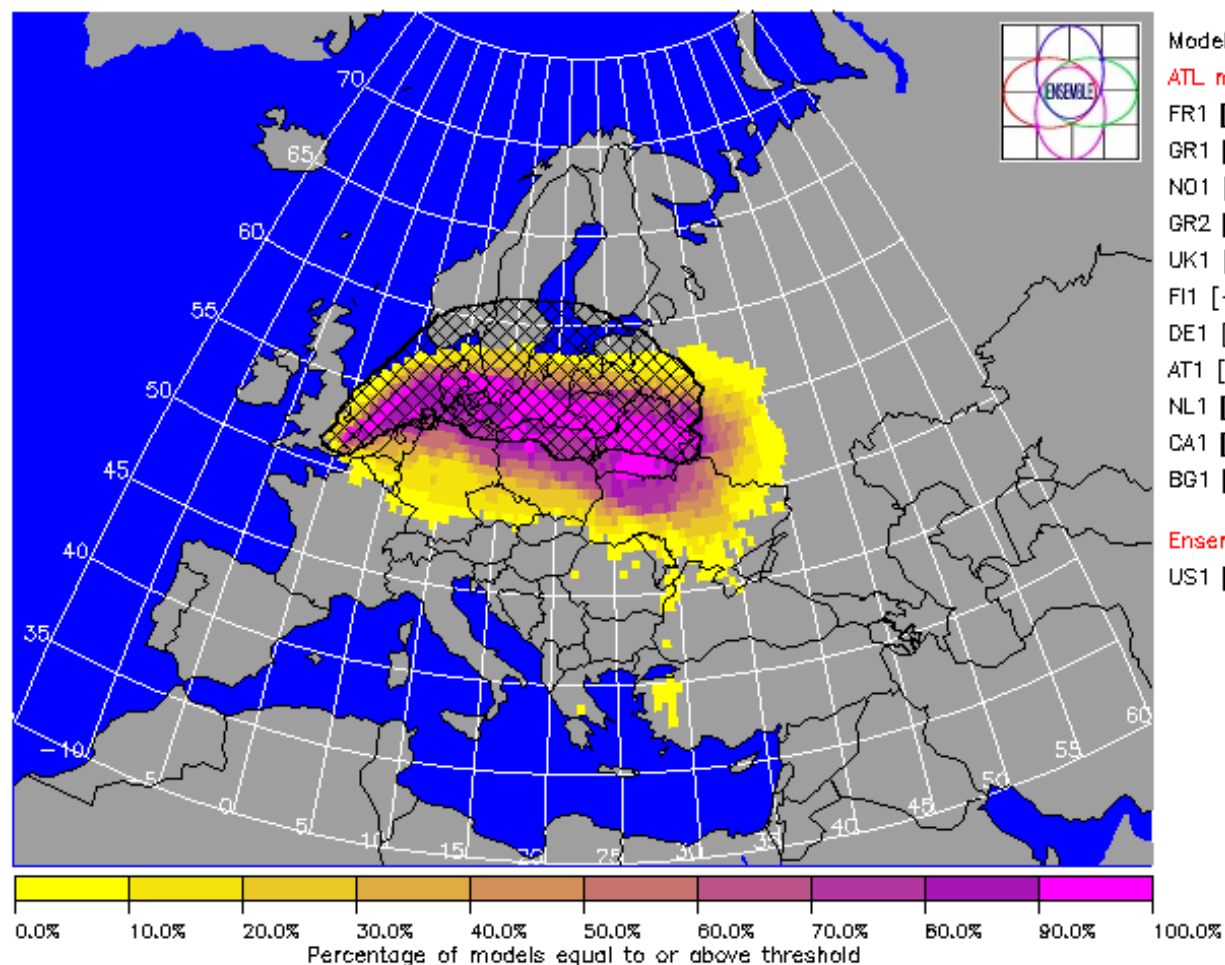

Projection: Lamberteizimuthal

Created by user rbuckley on 2003-06-20 16:34:07 UT0

Figure 12: Experiment 10 Results: Release of $\mathrm{Cs}^{137}$ from London, England on 11 June, 2003.
Release from London (UK) Location: 00:00 E 51:33 N Stort: 2003-06-11 12:00 UTO Duration: 900 s hours

Model(s) [delta meteo/delta upload] members:

[ $1+0 h 0 \mathrm{~m} /+24 h 18 \mathrm{~m}]$ [+OhOm/+5h16m] $\mathrm{GR} 2[+0 \mathrm{~h} 0 \mathrm{~m} /+22 \mathrm{~h} 53 \mathrm{~m}]$ KK1 $[-6 \mathrm{hOm} /-1 \mathrm{~h} 18 \mathrm{~m}]$ Fl1 [-6h0m/ $\left.44 \mathrm{~h}_{3} 4 \mathrm{~m}\right]$ DE1 [-12h0m/-3h9m] AT1 $[-12 \mathrm{~h} 0 \mathrm{~m} /-2 \mathrm{~h} 49 \mathrm{~m}]$ NL1 $[-12 \mathrm{hOm} /-3 \mathrm{~h} 24 \mathrm{~m}]$ CA1 $[-12 \mathrm{hOm} /+7 \mathrm{~h} 26 \mathrm{~m}]$ G1 $[-12 \mathrm{hOm} /-0 \mathrm{~h} 37 \mathrm{~m}]$ Ensemble (crosshatch): none us1 $[-12 \mathrm{hOm} /-\mathrm{Oh} 18 \mathrm{~m}]$ 
Exercise 11 - Agreement on threshold level for time-integrated concentration of Pu241 Date and time: 2003-06-14 00:00 UTC ( $+60 \mathrm{hOm}$ after reledse start)

Threshold level $=0.001 \mathrm{Bgh} / \mathrm{m}^{\mathrm{s}}$

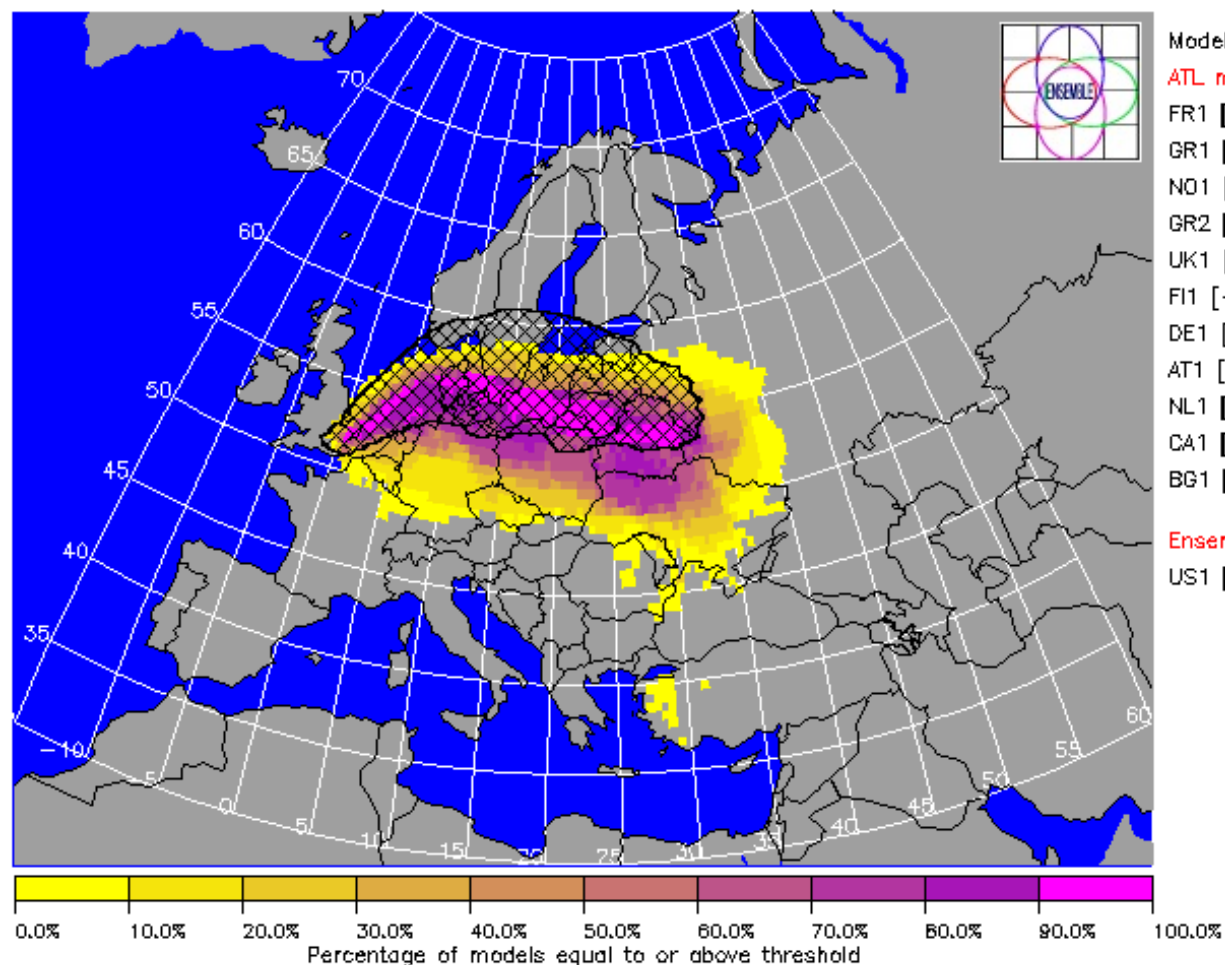

Projection: Lamberteizimuthal

Created by user rbuckley on 2003-06-20 16:35:34 UT0

Figure 13: Experiment 11 Results: Release of Pu ${ }^{241}$ from London, England on 11 June, 2003.
Release from London (UK) Location: 00:00 E 51:33 N Stort: 2003-06-11 12:00 UTO Duration: 900 s hours

Model(s) [delta meteo/delta upload] members:

$+0 \mathrm{~h} 0 \mathrm{~m} /+24 \mathrm{~h} 20 \mathrm{~m}]$ $+0 \mathrm{hOm} /+7 \mathrm{~h} 16 \mathrm{~m}]$ $[-6 \mathrm{hOm} /-\mathrm{Oh} 14 \mathrm{~m}]$ $-6 \mathrm{~h} 0 \mathrm{~m} /+44 \mathrm{~h} 58 \mathrm{~m}]$ $[-12 \mathrm{~h} 0 \mathrm{~m} /-2 \mathrm{~h} 47 \mathrm{~m}]$ NL1 $[-12 \mathrm{hOm} /-3 \mathrm{~h} 17 \mathrm{~m}]$ CA1 $[-12 \mathrm{hOm} /+7 \mathrm{~h} 23 \mathrm{~m}]$ G1 $[-12 \mathrm{hOm} /+1 \mathrm{~h} 16 \mathrm{~m}]$ Ensemble (crosshatch): none us1 $[-12 \mathrm{hOm} /+0 \mathrm{~h} 47 \mathrm{~m}]$ 